Federal Reserve Bank of Minneapolis

Research Department

\title{
RELATIVE PRICE MOVEMENTS IN DYNAMIC GENERAL EQUILIBRIUM MODELS OF INTERNATIONAL TRADE
}

David Backus, Patrick Kehoe, and Finn Kydland*

Working Paper 498

June 1992

NOT FOR DISTRIBUTION

WITHOUT AUTHOR APPROVAL

\begin{abstract}
We examine the behavior of international relative prices from the perspective of dynamic general equilibrium theory, with particular emphasis on the variability of the terms of trade and the relation between the terms of trade and net exports. We highlight aspects of the theory that are critical in determining these properties, contrast our perspective with those of earlier theories of trade and relative prices, and point out features of the data that have proved difficult to explain within existing dynamic general equilibrium theory.
\end{abstract}

Keywords: terms of trade; net exports; balance of trade; Marshall-Lerner condition; HarbergerLaursen-Metzler effect; $\mathbf{j}$ curve

JEL Classification Codes: F11, F30, F41

*Backus, Stern School of Business, New York University; Kehoe, University of Minnesota and Federal Reserve Bank of Minneapolis; Kydland, Carnegie Mellon University. We thank the National Science Foundation, the Institute for Empirical Macroeconomics, and the Center for Japan-U.S. Business and Economic Studies faculty fellowship program for financial support.

The views expressed herein are those of the authors and not necessarily those of the Federal Reserve Bank of Minneapolis or the Federal Reserve System. 


\section{o. Introduction}

Relative prices are the central feature of both the pure theory of international trade and open economy macroeconomics. Although the emphasis differs in the two branches of international economics, to a great extent the same theory underlies theoretical and empirical work in each. Applications of dynamic general equilibrium theory, or international real business cycle theory, continues this tradition by extending, at the aggregate level, several of the features of static trade theory to dynamic and stochastic settings. What it adds, we think, is a deeper understanding of the dynamics of trade and relative prices.

The Marshall-Lerner condition is, without question, the most common link between trade theory and international macroeconomics. In trade theory, this elasticity condition on import demand functions determines the direction of many comparative statics exercises and serves as a stability condition on an otherwise static theory, telling us whether a disequilibrium adjustment process will succeed in establishing equilibrium. In international macroeconomics, the same condition is used to establish a positive association between the trade balance and the terms of trade or real exchange rate. This is the level at which the theory is presented in most textbooks and, indeed, in the popular Mundell-Fleming and Dornbusch macroeconomic models of open economies.

The macroeconomic branch of international economics has also developed insights that are largely independent of the theory of trade. The absorption approach focused on the accounting relation between saving, investment, and the balance of trade. What distinguishes this work from static trade theory is its suggestion that the trade balance, or the closely related current account, is part of a dynamic process, the decision by an aggregate economy to lend or borrow in international capital markets. A critical development for understanding the relation between trade and relative prices stemmed from the recognition that any dependence of the trade balance on the terms of trade implied, as a matter of accounting, a similar relation with international borrowing and lending. This connection was noted by Harberger (1950) and Laursen and Metzler (1950) and later incorporated by obstfeld (1982) and Svensson and Razin (1983), among others, into explicitly dynamic theories of the balance of trade. These later papers contrasted the impact 
on the trade balance of permanent and transitory price changes. The impact, in their analysis, is a comparison between two deterministic equilibria.

We approach trade and relative price dynamics from a somewhat different theoretical tradition, that of dynamic general equilibrium theory. Like much of static trade theory, we use competitive consumers and producers. Unlike that work, however, our theory is explicitly dynamic. And unlike the modern approach to the Harberger-Laursen-Metzler effect, we consider not comparisons between different deterministic equilibria, but properties of equilibria for stochastic theoretical economies. We perform in the theory the same experiment that applied economists do in the data: we look at correlations between trade and relative price variables along an equilibrium path. Somewhat to our surprise, this approach leads to substantially different views of trade and price behavior than suggested by earlier work.

The application of dynamic general equilibrium theory to international trade has also led, in a rapidly growing number of papers, to attempts to quantify the theory's properties and compare them to properties of national economies. These attempts have led to a clearer understanding of which features of the data can be accounted for by the present state of theory, and which remain anomalous. This quantitative focus generates sharper predictions than qualitative theory, and helps to focus further theoretical work on clearly defined issues.

We elaborate on the twin themes of theoretical development and quantitative properties in the rest of the paper. We start, in Section 1, by documenting some of the salient features of aggregate trade and relative prices for a number of industrialized countries. These features make explicit the objects of interest in theoretical economies and serve as a basis of comparison for the theory.

We develop the theory in a series of two-country worlds, highlighting as we go the roles played by different theoretical features. Section 2 is devoted to an exchange economy in which each country specializes in a single traded good. Here the variability of relative prices and the relation between prices and trade are governed by a single parameter: the elasticity of substitution between foreign and domestic goods. Some of the quantitative properties of this economy change when we consider preferences that are not 
additively separable between foreign and domestic goods and that favor consumption of home goods. This aspect of the theory is developed in Section 3. We find, among other things, that agents' risk aversion plays a role in both the dynamics of trade and prices and the relation between these two variables.

In Section 4 we compare this theory with the Marshall-Lerner condition and the Harberger-Laursen-Metzler effect. We show that our elasticity condition is unrelated to the Marshall-Lerner condition, which is always satisfied in our symmetric economy. With respect to the HarbergerLaursen-Metzler effect we find that the persistence of shocks is orthogonal to the relation between relative prices and the balance of trade: for given preference parameters, the correlation between trade and prices is the same whether price changes last one period or one hundred. In both of these cases, dynamic general equilibrium theory provides a different perspective on trade and price fluctuations than earlier work.

In the remaining sections we consider extensions of the theoretical structure that change some of its quantitative features and broaden the theory's predictions. In Section 5 we consider shocks to government spending as well as to aggregate endowments. As one might expect, this extension has the potential to change equilibrium comovements considerably. We find, for example, that the sign of the relation between the trade balance and the terms of trade depends on the relative sizes of shocks to endowments and government spending, as well as the elasticity of substitution.

In Section 6 we imbed the exchange structure of earlier sections into an economy with endogenous labor supply and capital formation. The critical element here is capital formation. With this modification, we find that the dynamics of trade now reflect, to a large extent, cyclical fluctuations in physical investment. The most striking result is an asymmetric cross-correlation function for the trade balance and the terms of trade, which we label the J-curve. This feature does not arise in exchange economies, where by construction investment is zero and the cross correlation function is symmetric. In this sense the dynamics of capital formation play an important role in connecting the dynamics of the trade balance and the relative price of foreign and domestic goods. 
We conclude with a few remarks on the strengths and weaknesses of existing dynamic general equilibrium theories of trade, and suggestions for directions the theory might take in the future.

\section{First Look at the Data}

Since the ultimate objective of our theory is to account for empirical regularities, we start by looking at some of the properties of international relative prices. We focus here on three variables. The terms of trade, denoted $\mathrm{p}$, is the ratio of the import price deflator to the export price deflator, both taken from national income and product accounts. Net exports, denoted $\mathrm{nx}$, is the ratio of exports minus imports, in current prices, to output in current prices. Real output, denoted $y$, is GDP or GNP, depending on the country, in base-year prices (generally 1985). All three variables are constructed from data taken from the OECD's Quarterly National Accounts.

In Table 1 we report various properties of the terms of trade for three countries: Japan, the United Kingdom, and the United States. These statistics refer to Hodrick-Prescott (1980) filtered variables, and both the terms of trade and real output are logarithms. Many of the same properties are reported in Backus, Kehoe, and Kydland (1991) for a larger set of countries but a shorter time period. In Table 1 the sample period runs from 1955:2 to 1989:4, which enables us to look separately at the periods before and after the collapse of Bretton Woods.

We see, for a start, that movements in the terms of trade have been both variable and persistent. The standard deviation of terms of trade fluctuations ranges from 2.71 percent in the United Kingdom to 5.97 percent in Japan. Both here and in our earlier paper, variability of the terms of trade is considerably larger in Japan than we find for other countries. We are unsure, at this point, how much of this additional variability reflects true relative price movement and how much differences in the manner in which trade prices are constructed. Both Alterman (1989) and Graboyes (1991) raise serious questions concerning the quality of current trade prices in the United States, and it is likely that these problems are greater in earlier periods and other countries. Nevertheless, we are probably on safe ground in claiming substantial variability of the terms of trade in all countries. 
Persistence is evident in the autocorrelations, which are generally in the neighborhood of 0.8. Table 1 also verifies that there has been much more variability of the terms of trade since the advent of floating exchange rates than before, a feature stressed by Mussa (1986) for real exchange rates (ratios of consumer price indexes converted at spot exchange rates). Standard deviations of the terms of trade are typically two to three times larger in the later period.

We also include, in Table 1, correlations of the terms of trade with net exports and real output. With respect to net exports, we find greater coherence across periods, but little across countries. The terms of trade and net exports have generally been positively associated in the United States, negatively associated in Japan and the United Kingdom. We see in Table 2, which covers the post-Bretton Woods period for ten countries, that the US is an outlier in this regard: the correlation between the trade balance and the terms of trade is negative for every other country. With respect to output, there has been no regularity in the correlation with the terms of trade, either over time or across countries.

The contemporaneous correlation between net exports and the terms of trade misses an important regularity that appears when we examine the complete cross-correlation function: the correlations, that is, between $\mathrm{p}_{t}$ and $\mathrm{nx}_{\mathrm{t}+\mathrm{k}}$, for various leads and lags $\mathrm{k}$. The contemporaneous correlation refers to $\mathrm{k}=0$. For positive $\mathrm{k}$ the correlations pertain to net exports and past prices, and for positive $k$ the reverse. We find for Japan and the United Kingdom that this function has an asymmetric $\mathrm{S}$ shape; we label it the J-curve because it captures some of the same features of the data as work under that name. For Japan and the UK this feature appears not only in the postwar period as a whole, but in the pre- and post-Bretton-Woods subperiods as well. For the US the same pattern is evident only in the earlier period. Our earlier paper (Backus, Kehoe, and Kydland, 1991, Figure 1) documents this pattern in eight of eleven countries.

In the remainder of the paper, we examine these properties from the perspective of a series of successively more complex dynamic general equilibrium models, bringing additional data to bear when the theory suggests it. For now, we note that the terms of trade has been highly variable and persistent in all three countries, that the sign of its correlation with net 
exports differs across countries, and that the cross-correlation function for net exports and the terms of trade is often asymmetric (the J-curve property).

\section{A Dynamic Exchange Economy}

One of the simplest dynamic general equilibrium models of a world economy has two countries who trade specialized endowments. Let us say, in the interest of concreteness, that time $t$ runs from an initial date 0 to $a$ terminal date $T$, possibly infinite. The evolution of this endowment is stochastic, adapted to a "Debreu tree." We describe this tree in notation adapted from Lucas (1984). The state $z^{t}$, an element of the set $z^{t}$, denotes the history of the economy from date 0 through $t$. Each of these possible states occurs with a probability $\pi\left(\mathrm{z}^{\mathrm{t}}\right)$. Country 1 , which we call the home country, is endowed with the stream of positive quantities of the home good, denoted $\left\{\mathrm{y}_{1}\left(\mathrm{z}^{\mathrm{t}}\right)\right\}$, adapted to $\left\{\mathrm{z}^{\mathrm{t}}\right\}$. Likewise, country 2 , the foreign country, is endowed with the positive sequence $\left\{y_{2}\left(z^{t}\right)\right\}$ of quantities of the foreign good. We denote the prices of the domestic and foreign goods in state $z^{t}$ by $\mathrm{q}_{1}\left(\mathrm{z}^{\mathrm{t}}\right)$ and $\mathrm{q}_{2}\left(\mathrm{z}^{\mathrm{t}}\right)$. We define the terms of trade, $\mathrm{p}\left(\mathrm{z}^{\mathrm{t}}\right)=\mathrm{q}_{2}\left(\mathrm{z}^{\mathrm{t}}\right) / \mathrm{q}_{1}\left(\mathrm{z}^{\mathrm{t}}\right)$, as the relative price of imports to exports.

Each country is represented by a single consumer, who stands in for a large number of like agents. The preferences of the consumer of country $i$ are characterized by the expected utility function

$$
U_{i}=\sum_{t=0}^{T} \beta^{t} \sum_{z^{t} \in Z^{t}}^{t} \pi\left(z^{t}\right) u\left[c_{i}\left(z^{t}\right)\right],
$$

with $0<\beta<1, u(c)=c^{1-\gamma} /(1-\gamma)$, and $\gamma>0$. We refer to $\gamma$ as the risk aversion parameter. Both agents consume composites of the foreign and domestic goods, described by the Armington aggregator functions,

with

$$
c_{1}\left(a_{1}, b_{1}\right)=G\left(a_{1}, b_{1}\right), \quad c_{2}\left(b_{2}, a_{2}\right)=G\left(b_{2}, a_{2}\right) \text {, }
$$

$$
G(a, b)=\left[\omega a^{1-\alpha}+b^{1-\alpha}\right]^{1 /(1-\alpha)} .
$$

Thus the consumer of country 1 consumes a combination of foreign and domestic goods, as expressed in the function G. This theoretical device, due to Armington (1969), is widely used in computable static general equilibrium trade models. In this economy it is equivalent to giving consumers 
preferences over foreign and domestic goods directly. The two parameters, $\alpha>0$ and $\omega>0$, govern the elasticity of substitution and shares of foreign and domestic goods. The elasticity is $\sigma=1 / \alpha$. With $\omega=1$ the two consumers have identical preferences, and with $\omega>1$ they exhibit a preference for home goods: if home and foreign goods sell for the same price, the share of home goods is greater than one-half.

A competitive equilibrium in this economy consists of state-contingent quantities $\left(a_{i}, b_{i}\right)$ and prices $\left(q_{i}\right)$, such that $(a)$ consumer's maximize utility given prices and budget constraints and (b) quantities satisfy the resource constraints,

$$
\begin{aligned}
& y_{1}=a_{1}+a_{2}, \\
& y_{2}=b_{1}+b_{2} .
\end{aligned}
$$

We find it convenient to compute an equilibrium using the Negishi-Mantel algorithm. For any initial distribution of resources, a competitive allocation is associated with a Pareto optimum. Each optimum is the solution to a problem of the form: for some choice of welfare weights $\left(\lambda_{1}, \lambda_{2}\right)$, choose quantities $\left(a_{1}, a_{2}, b_{1}, b_{2}\right)$ in each state to maximize $\Sigma_{i} \lambda_{i} U_{i}$, subject to the resource constraints. The supporting prices can then be identified with the Lagrange multipliers on the constraints or derived from consumers' first-order conditions. Backus (1992, Section 2) describes this procedure in a similar context.

For the optimum problem, let us denote the Lagrange multipliers on the resource constraints in state $z^{t}$ by $q_{1}\left(z^{t}\right)$ and $q_{2}\left(z^{t}\right)$ for the domestic and foreign goods, respectively. If, for each $i$, we define spot price functions $Q_{i}$ by $q_{i}\left(z^{t}\right)=\beta^{t} \pi\left(z^{t}\right) Q_{i}\left(z^{t}\right)$, then the optimum problem separates into a number of identical problems, one for each state. The first-order conditions for each state have the form,

$$
\begin{aligned}
& \mathrm{Q}_{1}=\lambda_{1} \mathrm{c}_{1}\left(\mathrm{a}_{1}, \mathrm{~b}_{1}\right)^{\alpha-\gamma} \mathrm{a}_{1}^{-\alpha}=\lambda_{2} \mathrm{c}_{2}\left(\mathrm{a}_{2}, \mathrm{~b}_{2}\right)^{\alpha-\gamma} \mathrm{a}_{2}^{-\alpha}, \\
& \mathrm{Q}_{2}=\lambda_{1} \mathrm{c}_{1}\left(\mathrm{a}_{1}, \mathrm{~b}_{1}\right)^{\alpha-\gamma} \mathrm{b}_{1}^{-\alpha}=\lambda_{2} \mathrm{c}_{2}\left(\mathrm{a}_{2}, \mathrm{~b}_{2}\right)^{\alpha-\gamma} \mathrm{b}_{2}^{-\alpha} .
\end{aligned}
$$

The equilibrium terms of trade is $\mathrm{p}=\mathrm{Q}_{2} / \mathrm{Q}_{1}$.

In this section we restrict ourselves to the case of identical preferences, $\omega=1$, for which the analysis can be done analytically. The 
equilibrium allocation is then

$$
a_{i}=s_{i} y_{1}, \quad b_{i}=s_{i} y_{2} \text {, }
$$

for countries $i=1,2$ with consumption shares $s_{i}=\lambda_{i}^{1 / \gamma} / \Sigma_{j} \lambda_{j}^{1 / \gamma}$ that sum to one. The supporting prices are, up to a factor of proportionality,

$$
\mathrm{Q}_{\mathrm{i}}=\mathrm{y}_{\mathrm{i}}^{-\alpha},
$$

and the equilibrium terms of trade is

$$
\mathrm{p} \equiv \mathrm{q}_{2} / \mathrm{q}_{1}=\mathrm{Q}_{2} / \mathrm{Q}_{1}=\left(\mathrm{y}_{2} / \mathrm{y}_{1}\right)^{-\alpha} \text {. }
$$

The trade balance in country 1 is, in units of the domestic good,

$$
\mathrm{nx}_{1}=\mathrm{y}_{1}-\left(\mathrm{a}_{1}+\mathrm{pb}_{1}\right) .
$$

In equilibrium the ratio of the trade balance to output (the form of the trade variable used in Table 1) is

$$
\mathrm{nx}_{1} / \mathrm{y}_{1}=\left(1-\mathrm{s}_{1}\right)-\mathrm{s}_{1}\left(\mathrm{y}_{2} / \mathrm{y}_{1}\right)^{1-\alpha} \text {. }
$$

Along any equilibrium path for this economy the welfare weights, $\lambda_{i}$, are constant. Since the consumption shares, $s_{i}$, are functions of the welfare weights alone, they are constant as well. Thus fluctuations in both the trade balance and the terms of trade are driven, along any equilibrium path, only by movements in the endowment ratio, $y_{2} / y_{1}$. In this sense, the equilibrium prices and quantities are functions of a single state variable, the ratio $y_{2} / y_{1}$, and are thus indirectly related to each other.

Although the theory is fairly simple, we can start to compare some of its properties with those of the data -- in particular, the variability and persistence of the terms of trade, $p$, and the correlation of the terms of trade with net exports. It's clear that the variability of $p$ is governed by the variability of the endowment ratio, $y_{2} / y_{1}$, and the substitution parameter $\sigma=1 / \alpha$. A given amount of variability of the endowment ratio can produce as much price variability as we like if $\sigma$ is small enough. As an example, consider the standard deviation of the US terms of trade reported in Table 1: 3 percent, for the period as a whole. This refers to the standard deviation of the Hodrick-Prescott filtered logarithm. The standard deviation of the filtered logarithm of (to be specific) the ratio of US to Japanese output is about 2.2. To generate the amount of price variability we see in the US, then, we need an elasticity of about $\sigma=0.73$ (since 2.2/0.73=3.0). This is only a rough calculation, since the data refer to a world with more than one 
country and in which a large part of the variability of output appears in investment, which is obviously absent here. But it is suggestive of the role played by the elasticity of substitution in generating relative price variability. As a rule, the theory can produce any amount of price variability we like if the elasticity of substitution $\sigma$ is a free parameter.

With regard to persistence, the terms of trade inherits the autocorrelation properties of the endowment ratio. To continue our example, the autocorrelation of the US/Japan output ratio (the filtered logarithm, that is) is 0.7 , so the autocorrelation of the terms of trade, in our theory, is also 0.7. This is slightly less than we see for the US terms of trade in Table 1, but the discrepancy is not large, either economically or statistically.

The final issue concerns the relation between the trade balance and the terms of trade. The contemporaneous relation is summarized in

Proposition 1. Let $\omega=1$. Then the sign of the relation between the trade balance, $\mathrm{nx}_{1} / \mathrm{y}_{1}$, and the terms of trade, $\mathrm{p}$, is governed by $\sigma=1 / \alpha$, the elasticity of substitution between foreign and domestic goods. If $\sigma>1$ the two variables are positively related, and if $\sigma<1$ they are negatively related.

A similar result is implicit in Stockman and Svensson (1987, Section 5.3). The proof consists of examining the equilibrium values of the trade balance and the terms of trade. Both are monotonic functions of the endowment ratio, $y_{2} / y_{1}$. The price is a decreasing function in all cases. The trade balance is increasing if $\sigma=1 / \alpha<1$, decreasing if $\sigma=1 / \alpha>1$, as you can see by inspection. If $\sigma=1$ the trade balance is constant, as noted recently by Cole and Obstfeld (1991). Except for nonlinearities, the correlations are either +1 or -1 , except for $\sigma=1$, when the trade balance is constant and the correlation is not defined.

The dynamics of the relation relation between trade and prices, like the dynamics of prices, are determined completely by the dynamics of the endowment ratio. Except for nonlinearities, the cross-correlation function for the trade balance and the terms of trade is the same as the autocorrelation function of the endowment ratio. By way of example, suppose the logarithm of the endowment ratio is AR(1), with autocorrelation $\rho>0$. 
Then if $\sigma>1$ the cross-correlation function for the trade balance and the terms of trade is tent-shaped: the contemporaneous correlation is +1 , and the correlation between $\mathrm{p}_{\mathrm{t}}$ and $\mathrm{nx}_{\mathrm{t}+\mathrm{k}}$ is $\rho|\mathrm{k}|$. If $\sigma<1$ the function is $v$-shaped. Even with other autocorrelation patterns, the cross-correlation function will be symmetric since the autocorrelation function is. The exchange economy, then, is incapable of reproducing the asymmetric correlation functions pictured in Figure 1.

\section{Preference for Home Goods}

When consumers in the two countries have preferences that favor their respective home goods ( $\omega>1$ in the Armington aggregator $G$ ), the behavior of trade and prices changes somewhat. When preferences for domestic and foreign goods are not additively separable, we find that the risk aversion parameter, $\gamma$, as well as the elasticity of substitution between foreign and domestic goods, $\sigma=1 / \alpha$, plays a role in the relation between the trade balance and the terms of trade.

The simplest case is $\gamma=\alpha$ : risk aversion $(\gamma)$ is the inverse of the substitution elasticity for foreign and domestic goods $(\sigma=1 / \alpha)$. With this restriction preferences, including the aggregator, are additively separable between the foreign and domestic goods, which simplifies the analysis considerably. We compute an equilibrium, as before, from an optimum. The reader may readily verify that the equilibrium allocations, for countries $\mathrm{i}=1,2$, are

$$
a_{i}=s_{i}^{a} y_{1}, \quad b_{i}=s_{i}^{b} y_{2},
$$

where the consumption shares, $s_{1}^{a}=\left(\omega \lambda_{1}\right)^{1 / \gamma} /\left[\left(\omega \lambda_{1}\right)^{1 / \gamma}+\lambda_{2}{ }^{1 / \gamma}\right], s_{2}^{a}=1-s_{1}^{a}, s_{1}^{b}=$ $\lambda_{1}{ }^{1 / \gamma_{1}}\left[\lambda_{1}{ }^{1 / \gamma_{+}}+\left(\omega \lambda_{2}\right)^{1 / \gamma}\right]$, and $s_{2}^{b}=1-s_{1}^{b}$, are constant along any equilibrium path. The only difference from the symmetric case is that the consumption shares now differ across goods, with larger values of $\omega$ leading to larger shares of domestic good consumption, $s_{1}^{a}$ and $s_{2}^{b}$. The supporting prices are

$$
\begin{aligned}
& \mathrm{Q}_{1}=\left[\left(\omega \lambda_{1}\right)^{1 / \gamma}+\lambda_{2}{ }^{1 / \gamma}\right]^{\alpha} \mathrm{y}_{1}{ }^{-\alpha}, \\
& \mathrm{Q}_{2}=\left[\lambda_{1}^{1 / \gamma_{+}}+\left(\omega \lambda_{2}\right)^{1 / \gamma}\right]^{\alpha} \mathrm{y}_{2}{ }^{-\alpha},
\end{aligned}
$$

so the equilibrium terms of trade is 


$$
\mathrm{P} \equiv \mathrm{Q}_{2} / \mathrm{Q}_{1}=\left(\omega \mathrm{s}_{1}^{\mathrm{b}} / \mathrm{s}_{1}^{\mathrm{a}}\right)^{\alpha}\left(\mathrm{y}_{2} / \mathrm{y}_{1}\right)^{-\alpha}
$$

As before, the relative price $\mathrm{p}$ is driven by the endowment ratio. The only change is the factor of proportionality, which does not affect the properties of the logarithm of p. The variability of the terms of trade is determined by the variability of the endowment ratio, $y_{2} / y_{1}$, and the elasticity of substitution, $\sigma=1 / \alpha$.

The trade balance for country 1 in this economy, expressed as a ratio to domestic output, is

$$
\mathrm{nx}_{1} / \mathrm{y}_{1}=\left(1-\mathrm{s}_{1}^{a}\right)-\mathrm{s}_{1}^{\mathrm{b}}\left(\mathrm{y}_{2} / \mathrm{y}_{1}\right)^{1-\alpha} \text {. }
$$

We can see that preference for home goods $(\omega>1)$ has the effect of damping fluctuations in the balance of trade, in the sense that larger values of $\omega$ imply smaller values of $s_{1}^{b}$. Comovements, however, do not change: the sign of the effect of the endowment ratio on the balance of trade once more hinges on whether $\alpha=1 / \sigma$ is greater or less than one and does not depend on any other parameters. Thus the properties described in the previous section for identical preferences $(\omega=1)$ apply to this economy as well.

It's clear, then, that any influence of the home preference parameter on price behavior must operate through nonseparabilities between domestic and foreign goods -- different values of $\alpha$ and $\gamma$. For the general case, the first-order conditions of the optimum problem are, as reported earlier,

$$
\begin{aligned}
& \mathrm{Q}_{1}=\lambda_{1} \mathrm{c}_{1}\left(\mathrm{a}_{1}, \mathrm{~b}_{1}\right)^{\alpha-\gamma} \omega \mathrm{a}_{1}^{-\alpha}=\lambda_{2} \mathrm{c}_{2}\left(\mathrm{a}_{2}, \mathrm{~b}_{2}\right)^{\alpha-\gamma} \mathrm{a}_{2}^{-\alpha}, \\
& \mathrm{Q}_{2}=\lambda_{1} \mathrm{c}_{1}\left(\mathrm{a}_{1}, \mathrm{~b}_{1}\right)^{\alpha-\gamma} \mathrm{b}_{1}^{-\alpha}=\lambda_{2} \mathrm{c}_{2}\left(\mathrm{a}_{2}, \mathrm{~b}_{2}\right)^{\alpha-\gamma} \omega \mathrm{b}_{2}^{-\alpha} .
\end{aligned}
$$

The allocation of goods between countries is influenced, in this case, by the sign of $\alpha-\gamma$.

The equilibrium conditions do not admit a simple analytic solution, but the intuition is fairly straightforward. As before, the variables of interest are functions of the endowment ratio, $x=y_{2} / y_{1}$. In states with high values of $\mathrm{x}$, we find that the ratios of foreign to domestic good consumption, $\mathrm{b}_{\mathrm{i}} / \mathrm{a}_{\mathrm{i}}$, and the aggregate consumption ratios, $\mathrm{c}_{2} / \mathrm{c}_{1}$, are also high: they are increasing functions, in other words, of the endowment ratio $x$. Neither property is surprising: if there is relatively more of the foreign good, 
then in equilibrium both agents consume relatively more, and aggregate consumption favors the country whose preferences weight the foreign good more (country 2, since $\omega>1$ ). Proofs of both of these propositions are included in the appendix.

From this starting point we can describe the effects on the relative price of the foreign good and the balance of trade. We start with the price. From the first-order conditions, we see that the terms of trade satisfies the relations:

$$
p=\omega^{-1}\left(b_{1} / a_{1}\right)^{-\alpha}=\omega\left(b_{2} / a_{2}\right)^{-\alpha} .
$$

Since $b_{1} / a_{1}$ and $b_{2} / a_{2}$ are increasing functions of the endowment ratio $x$, the terms of trade is a decreasing function. Thus an increase in the relative supply of the foreign good lowers its relative price. With somewhat greater effort we can characterize the magnitude of the decline. The first step is to relate the endowment ratio to $b_{1} / a_{1}$. The resource constraints imply

$$
x \equiv y_{2} / y_{1}=s_{1}^{b}\left(b_{1} / a_{1}\right)+\left(1-s_{1}^{b}\right)\left(b_{2} / a_{2}\right)=\left[s_{1}^{b}+\omega^{2 / \alpha}\left(1-s_{1}^{b}\right)\right]\left(b_{1} / a_{1}\right),
$$

where $s_{1}^{b}=b_{1} / y_{2}$ is the (possibly state-dependent) share of foreign good consumption in country 1 . Thus, with $\omega>1$, the proportional change in $b_{1} / a_{1}$ can be either greater or less than the proportional change in $\mathbf{x}$, depending on whether $s_{1}^{b}$ increases or decreases with $x$. The second step follows from the first-order conditions for the foreign good:

$$
\left(b_{1} / b_{2}\right)^{\alpha}=\left[s_{1}^{b} /\left(1-s_{1}^{b}\right)\right]^{\alpha}=\left(\omega \lambda_{2} / \lambda_{1}\right)\left(c_{2} / c_{1}\right)^{\gamma-\alpha} \text {. }
$$

Since $c_{2} / c_{1}$ is an increasing function of the endowment ratio, $s_{1}^{b}$ is increasing in $x$ if $\gamma>\alpha$, decreasing if $\gamma<\alpha$, and constant if $\gamma=\alpha$ (this being the additively separable case described earlier). Thus the (absolute value of the) slope of the relation between the logarithms of the terms of trade, $p$, and the endowment ratio, $x$, is greater than $\alpha$ if $\gamma>\alpha$, less than $\alpha$ if $\gamma<\alpha$, and equal to $\alpha$ (as we've already seen) if $\gamma=\alpha$. Other things equal, greater risk aversion tends to increase the variability of the terms of trade relative to that of the endowment ratio.

The contemporaneous relation between the trade balance and the terms of trade is characterized by 
Proposition 2. Let $\omega>1$ (preference for home goods). Then there is a positive number $\sigma^{*}$ that if $\sigma>\sigma^{*}$ the trade balance, $\mathrm{nx}_{1} / \mathrm{y}_{1}$, is positively related to the terms of trade, $p$, if $\sigma=>\sigma^{*}$, and negatively related if $\sigma=<\sigma^{*}$. Furthermore, if $\gamma>1$, then $\sigma^{*}>1$.

Thus the risk aversion parameter, $\gamma$, has an influence on comovements between the trade balance and the terms of trade. The proof consists largely of expressing the ratio of the trade balance to output in a convenient form. As in Proposition 1, both the trade balance and the terms of trade are monotonic functions of the endowment ratio $x=y_{2} / y_{1}$. The terms of trade is, for all parameter values, decreasing in $\mathrm{x}$. As for the trade balance, we let

$$
\mathrm{nx}_{1} / \mathrm{y}_{1}=\left(\mathrm{a}_{2}-\mathrm{pb}_{1}\right) / \mathrm{y}_{1}=1-\mathrm{s}_{1}^{\mathrm{a}}\left[1+\omega^{-1}\left(\mathrm{~b}_{1} / \mathrm{a}_{1}\right)^{1-\alpha}\right] .
$$

With $\omega=1, s_{1}^{a}$ is constant. Since $b_{1} / a_{1}$ is, as we have shown, increasing in the endowment ratio $\mathrm{x}=\mathrm{y}_{2} / \mathrm{y}_{1}$, the proposition follows immediately with $\sigma^{*}=1$. With $\omega>1$, the dependence of $s_{1}^{a}$ on $x$ introduces an additional element of dependence on $x$. If $\gamma>1$ and $\alpha<\gamma, s_{1}^{a}$ is increasing in $x$. Thus, for $\alpha \leq 1$ the trade balance is decreasing in $x$. By continuity this is true for values of $\alpha$ slightly greater than 1 as well. For large values of $\alpha$, however, the trade balance is increasing in $x$, as we show in the appendix (result 4). Thus there is a number $\alpha^{*}>1$, and $\sigma^{*}=1 / \alpha^{*}<1$, that divides the regions of positive and negative comovement between the trade balance and the terms of trade.

In short, the economy is much like the one of the previous section. Its similarities and differences are illustrated by the following example.

Example. There are two states, with unconditional probabilities $(1 / 2,1 / 2)$. (With two states nonlinearities are irrelevant, since two points can always be connected by a straight line.) Let the aggregate endowments $\left(y_{1}, y_{2}\right)$ of the domestic and foreign goods be $(1+\varepsilon, 1-\varepsilon)$ in state $1,(1-\varepsilon, 1+\varepsilon)$ in state 2, with $\varepsilon>0$. Thus the standard deviations of $y_{1}$ and $y_{2}$ are $\varepsilon$ and the standard deviation of the logarithm of the endowment ratio $y_{2} / y_{1}$ is, for small $\varepsilon$, approximately $2 \varepsilon$. The transition probabilities between states $\mathrm{i}$ and $\mathrm{j}$ are

$$
\left[\pi_{i j}\right]=\left[\begin{array}{ll}
(1+\rho) / 2 & (1-\rho) / 2 \\
(1-\rho) / 2 & (1+\rho) / 2
\end{array}\right] .
$$

The persistence parameter $\rho$ governs the autocorrelation function for any 
random variable adapted to the state, with the k-order autocorrelation equal to $\rho^{\mathrm{k}}$.

Case 1: identical preferences $(\omega=1)$. The terms of trade is

$$
\mathrm{p}=\left(\mathrm{y}_{2} / \mathrm{y}_{1}\right)^{-\alpha},
$$

which equals $[(1+\varepsilon) /(1-\varepsilon)]^{-\alpha}$ in state $1,[(1-\varepsilon) /(1+\varepsilon)]^{-\alpha}$ in state 2. The standard deviation of the logarithm of $p$ is, for small $\varepsilon$, approximately $\alpha(2 \varepsilon)$. With $\varepsilon=0.05$ and $\alpha=5$, the standard deviation is 0.500 . The ratio of the trade balance to output is

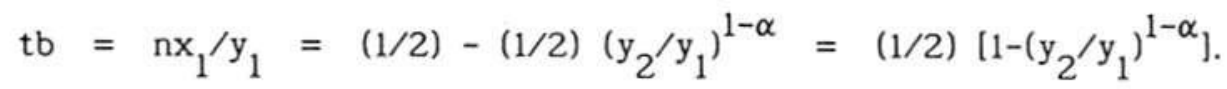

Thus for $\sigma=1 / \alpha<1$ the correlation between $\mathrm{e}$ and $\mathrm{nx}$ is -1 , for $\sigma>1$ the correlation is +1 . For $\alpha=1$ the trade balance is zero in both states and the correlation is not defined. The cross-correlation function for the trade balance and the terms of trade has the form:

$$
\operatorname{corr}\left(\mathrm{tb}_{\mathrm{t}}, \mathrm{p}_{\mathrm{t}+\mathrm{k}}\right)=\operatorname{sign}(\sigma-1) \rho^{|\mathrm{k}|},
$$

where $\sigma=1 / \alpha$. As noted earlier, this function is symmetric in $k$.

Case 2: preference for home goods $(\omega>1)$. To make this concrete, let $\varepsilon=0.05, \omega=2$, and $\gamma=2$. With $\alpha=5$ the standard deviation of the logarithm of the terms of trade is 0.497 , slightly smaller than in the case of identical preferences. There is a critical value $\sigma^{*}=0.885<1$ of the elasticity of substitution such that for $\sigma>\sigma^{*}$ the trade balance and the terms of trade are positively correlated, and for $\sigma<\sigma^{*}$ they are negatively correlated. The cross-correlation function is

$$
\operatorname{corr}\left(\mathrm{tb}_{\mathrm{t}}, \mathrm{p}_{\mathrm{t}+\mathrm{k}}\right)=\operatorname{sign}\left(\sigma^{*}-1\right) \rho^{|\mathrm{k}|},
$$

which remains symmetric.

\section{The Marshall-Lerner Condition and the Harberger-Laursen-Metzler Effect}

The theory of the last two sections, and its relation to time series data, are relatively straightforward. We have found, however, that it gives us a much different understanding of the relation between trade and relative prices than either the widely-cited Marshall-Lerner condition or the 1980s literature on the Harberger-Laursen-Metzler effect. In this section we 
compare our work to these other approaches and point out the differences among them.

The elasticity condition of Proposition 1 is an example of a common result in price theory, that the sign of the effect depends on whether utility is more or less concave then the $\log (\sigma=1)$. In that sense there is nothing surprising about it. What we find interesting in the present setting is the difference between this condition and the Marshall-Lerner condition, of ten cited as the determining factor in the sign of the relation between the trade balance and the terms of trade. The Marshall-Lerner condition is the centerpiece of textbook treatments of this issue; among many other examples, see Dornbusch (1980, p 59), Ethier (1988, pp 402-7), and Krugman and Obstfeld (1991, p 423).

The Marshall-Lerner condition applies to a static economy, but we can review its logic in a one-period version of our two-country world. Our treatment follows Kemp (1987). We start by deriving conditions on static import demand functions that allow us to express the balance of trade as an increasing function of the terms of trade. Among the conditions for equilibrium in the static economy are the resource constraint for the home good,

$$
a_{1}+a_{2}=y_{1}
$$

and the first agent's budget constraint,

$$
\mathrm{a}_{1}+\mathrm{pb}_{1}=\mathrm{y}_{1} .
$$

These conditions together imply balanced trade:

$$
\mathrm{nx}_{1}=\mathrm{a}_{2}-\mathrm{pb}_{1}=0 \text {. }
$$

Utility maximization by both agents, subject to their respective budget constraints, results in import demand functions, $a_{2}(p)$ and $b_{1}(p)$, say. These functions define net exports as a function of the terms of trade:

$$
\mathrm{nx}_{1}(\mathrm{p})=\mathrm{a}_{2}(\mathrm{p})-\mathrm{pb}_{1}(\mathrm{p}) \text {. }
$$

This function is increasing in $p$ if

$$
\varepsilon+\varepsilon^{*}>1,
$$

where

and

$$
\varepsilon=-\left(\partial \mathrm{b}_{1} / \partial \mathrm{p}\right)\left(\mathrm{p} / \mathrm{b}_{1}\right)
$$




$$
\varepsilon^{*}=\left(\partial \mathrm{a}_{2} / \partial \mathrm{p}\right)\left(\mathrm{p} / \mathrm{a}_{2}\right)
$$

are the domestic and foreign import elasticities. The inequality is the well known Marshall-Lerner condition.

We now apply this analysis to our economy. The relevant import demand functions are

$$
\begin{gathered}
b_{1}(p)=y_{1} /\left(p+p^{\sigma}\right) \\
a_{2}(p)=y_{2} p^{\sigma+1} /\left(p+p^{\sigma}\right),
\end{gathered}
$$

where, as before, $\sigma=1 / \alpha$ is the elasticity of substitution between foreign and domestic goods. The import elasticities are therefore

$$
\begin{aligned}
\varepsilon & =\left(1+\sigma p^{\sigma-1}\right) /\left(p+p^{\sigma}\right), \\
\varepsilon^{*} & =p^{\sigma}\left(\sigma+p^{\sigma-1}\right) /\left(p+p^{\sigma}\right) .
\end{aligned}
$$

Adding these two expressions together, we find that

$$
\varepsilon+\varepsilon^{*}=\sigma+1>1 .
$$

In other words, the Marshall-Lerner condition is always satisfied in this economy, regardless of the value of the elasticity of substitution between foreign and domestic goods.

Thus we see that the Marshall-Lerner condition has no connection with the elasticity condition of Proposition 1 and therefore has no bearing on the correlation between the trade balance and the terms of trade for time series data generated by economies like ours. The difference in results stems, we think, from the difference between dynamic modeling and the comparative statics experiments that underlie the Marshall-Lerner condition. Despite the intuitive appeal of the latter, we find that when the dynamics are worked out explicitly we get a different interpretation of this property of the data.

The theoretical state of the art regarding the relation between the trade balance and the terms of trade, however, is not the Marshall-Lerner condition but the 1980 s revival of the Harberger-Laursen-Metzler effect initiated by Obstfeld (1982) and Svensson and Razin (1983). These papers, and others that followed, start with the central insight of the absorption approach: that current account imbalances reflect differences between saving 
and investment. The theoretical economies of these two papers are deterministic but share with ours the feature that dynamics are explicit. They come, however, to much different conclusions regarding the factors that lead to a positive association between the trade balance and the terms of trade. These papers suggest that two factors are critical in determining the pattern of comovements: the persistence of the shock and the form of dependence of the discount factor, or rate of time preference, on future utility. Transitory shocks typically lead, in their analysis, to movements in the terms of trade and the trade balance of opposite sign. We find, in contrast, that there is complete mathematical separation between periods, and that the relation between the trade balance and the terms of trade is independent of the dynamics of prices. Obstfeld (1982) and Svensson and Razin (1983) also find that the effect of permanent shocks depends on the behavior of the discount factor. As Svensson and Razin (1983, p 100) put it: "A permanent terms-of-trade deterioration ... causes a deterioration or improvement in the real trade balance, depending on whether ... the rate of time preference decreases or increases, respectively, with the level of welfare." Obstfeld (1982) assumes that the rate of time preference is decreasing in future utility and therefore predicts a decline in the trade balance. In his words (1982, p 251), "an economy specialized in production must experience a fall in aggregate spending and a current [account] surplus as a result of an unanticipated, permanent worsening in its terms of trade." In both papers there is no effect on the trade balance if the rate of time preference is constant. In our economies, the rate of time preference is constant, fixed by the discount factor $\beta$. The conclusion should then be that permanent movements in the terms of trade have no effect on the trade balance. We find, instead, that the relation between the trade balance and the terms of trade is determined by the elasticity of substitution, regardless of the persistence of shocks.

Like our analysis of the Marshall-Lerner condition, the difference between our approach and that of the Harberger-Laursen-Metzler effect stems, in part, from our definition of the issue. In our analysis, the relation between the trade balance and the terms of trade pertains to the correlation between these two variables for the realization of a single time series, like the quarterly series for Japan, the UK, and the US described in Table 1. This corresponds, in our theoretical economies, to the correlation between the two variables along an equilibrium path. In the analysis of Obstfeld 
(1982) and Svensson and Razin (1983), however, the Harberger-Laursen-Metzler effect pertains to a comparison between two different deterministic equilibria: one in which the terms of trade is high, and one in which it is low. Apparently these two thought experiments emphasize much different features of the theory. We would argue that our thought experiment is closer to what we have in mind when we compare theory and data. A closer look also suggests, as brought out in Backus (1992) and Stockman and Svensson (1987), that the theory requires explicit treatment of the stochastic structure of the economy, something that deterministic analysis cannot provide.

In short, we've found that explicit dynamic stochastic analysis of trade and relative prices leads to much different views of the factors determining their comovements. Even the role of that textbook standard, the Marshall-Lerner condition, may need to be reconsidered.

\section{Government Spending}

The theory thus far has focused on fluctuations in trade and prices arising from movements in endowments. Here we consider an extension to the exchange economy of Section 2 in which we have, in addition, exogenous shocks to government spending. Related analyses have been provided by Baxter (1992), Hodrick (1988), Macklem (1991), Obstfeld (1989), and Yi (1991). We find this extension both interesting in its own right, and a useful step toward introducing a wide range of impulses into dynamic general equilibrium models of trade: shocks, for example, to taxes, tariffs, and possibly even monetary policies. To keep the analysis simple, we restrict ourselves to the case of symmetric preferences $(\omega=1)$.

In this new economy the government is an additional consumer of goods. Let us say, then, that in state $z^{t}$ the government of country i consumes the quantity $g_{i}\left(z^{t}\right)$ of the home good. This spending is financed with lump-sum taxes, $\tau_{i}\left(z^{t}\right)$ say. An equilibrium then consists of quantities $\left(a_{i}\right.$ and $\left.b_{i}\right)$, prices $\left(q_{i}\right)$, and government policies $\left(g_{i}, \tau_{i}\right)$ such that (a) consumer's maximize utility given prices and budget constraints, (b) quantities satisfy the resource constraints,

$$
y_{1}-g_{1}=a_{1}+a_{2}
$$




$$
y_{2}-g_{2}=b_{1}+b_{2},
$$

and (c) policies satisfy governments' budget constraints.

With this structure, the economy is equivalent to one with "net endowments" $y_{i}-g_{i}$, rather than $y_{i}$, and we can apply most of the results of Section 2 with little change. The equilibrium allocation includes

$$
a_{i}=s_{i}\left(y_{1}-g_{1}\right), \quad b_{i}=s_{i}\left(y_{2}-g_{2}\right),
$$

with consumption shares $s_{i}=\lambda_{i}^{1 / \gamma} / \Sigma_{j} \lambda_{j}^{1 / \gamma}$, for $i=1,2$, for some choice of welfare weights $\lambda_{i}$. The equilibrium terms of trade is

$$
p=\left[\left(y_{2}-g_{2}\right) /\left(y_{1}-g_{1}\right)\right]^{-\alpha} \text {. }
$$

The variability of the terms of trade is governed, then, by the variability of the net endowment ratio and the elasticity of substitution, $\sigma=1 / \alpha$. In practice, the addition of government purchases has little influence on the variance of $\mathrm{p}$, since $\mathrm{g}$ is only a fraction of output and is generally less variable. The same reasoning applies to persistence: introducing government purchases of goods and services does little to change our prediction that relative prices retain the persistence of output ratios.

The most interesting aspects of government purchases concern trade. If $\mathrm{w}_{\mathrm{i}}=\mathrm{y}_{\mathrm{i}}-\mathrm{g}_{\mathrm{i}}$ is the endowment net of government purchases, net exports in country 1 is

$$
\mathrm{nx}_{1}=\left(1-\mathrm{s}_{1}\right) \mathrm{w}_{1}-\left(\mathrm{w}_{2} / \mathrm{w}_{1}\right)^{-\alpha} \mathrm{s}_{1} \mathrm{w}_{2}=\mathrm{w}_{1}\left[\left(1-\mathrm{s}_{1}\right)-\mathrm{s}_{2}\left(\mathrm{w}_{2} / \mathrm{w}_{1}\right)^{1-\alpha}\right]
$$

The ratio of net exports to output is

$$
\mathrm{nx}_{1} / \mathrm{y}_{1}=\left[\left(1-\mathrm{s}_{1}\right)-\mathrm{s}_{2}\left(\mathrm{w}_{2} / \mathrm{w}_{1}\right)^{1-\alpha_{1}} \mathrm{w}_{1} /\left(\mathrm{w}_{1}+\mathrm{g}_{1}\right)\right. \text {. }
$$

In our earlier analysis, $g_{1}$ was zero and the last term was, therefore, one. As a result, the effect of the endowment ratio on the trade balance, and the association between movements in the trade balance, $\mathrm{nx}_{1} / \mathrm{y}_{1}$, and the terms of trade, $p$, depended only on the value of $\sigma=1 / \alpha$. For $\sigma<1$ the association was positive, for $\sigma<1$ the reverse. Here we find an additional factor, the ratio of the net endowment, $w_{1}$, to total output, $y_{1}=w_{1}+g_{1}$.

We can get some idea of the contributions of output and government 
spending shocks on trade and price fluctuations by considering special cases. Consider, first, the case in which $g_{1}$ is proportional to $y_{1}$. Then $w_{1} /\left(w_{1}+g_{1}\right)$ is constant, and the relation between the trade balance and the terms of trade is determined by $\sigma$, as it was in Proposition 1 . With $\sigma>1$ (or $\alpha<1$ ) the trade balance and the terms of trade are positively related along an equilibrium path, with $\sigma<1$ they are negatively related. Alternatively, suppose outputs $y_{i}$ are constant and $g_{1}$ is the only shock. Then the trade balance and the terms of trade are positively associated, regardless of the value of $\sigma$. This example is like many others in economics in which the comovement between two endogenous variables depends on the source of their fluctuations.

This suggests a second look at trade and price data, with special attention paid to government purchases $\mathrm{g}$. As we see in Table 2, there has been little regularity across countries in either the variability of government purchases, relative to that of real output, or in the correlation between these two variables. The same statement applies to the correlations of government purchases with the trade balance and the terms of trade. That is not to say that government purchases have not played a role in trade and price behavior, simply that this role is not simple enough to show up in summary statistics of this form. Froot and Rogoff (1991) document somewhat stronger indications of a relation between government spending and real exchange rates.

\section{Trade and Capital Formation}

In the exchange economies of Sections 2 and 3 we compared properties of the data with analogous properties of trade and relative prices in simple theoretical economies. This analysis brought up two questions that deserve a closer look. We found, for one thing, that the variability of the terms of trade is governed by the variability of the output ratio and the elasticity of substitution between foreign and domestic goods. By choosing a small enough elasticity the theory can generate literally any amount of relative price variability. The question, in this case, is whether the amounts of price variability in the theory and the data are close for reasonable values

of this elasticity. In another respect, we found that the exchange economy could not, for any choice of parameter values, mimic the data: the cross 
correlation function for the trade balance and the terms of trade. In the data this function is generally asymmetric, a feature we documented in Figure 1 and labeled the J-curve. In the exchange economy, however, the function is symmetric by construction, since both the trade balance and the terms of trade are functions of the same state variable. The question here is whether this property changes when we introduce physical capital formation.

The introduction of capital formation brings us closer to the theme of the absorption approach to the balance of payments: that fluctuations in trade reflect differences between saving and investment. At the level of accounting this connection is undeniable, but it also shifts one's attention away from intratemporal relative prices to the intertemporal decisions to save and invest. Thus Sachs (1981) argues that trade deficits of ten reflect investment booms, and Stockman and Svensson (1987) tie both trade and relative prices to fluctuations in, among other things, fixed capital formation. We continue this tradition by introducing capital formation to an economy that is otherwise like our earlier ones. The structure is adapted from Backus, Kehoe, and Kydland (1991). The emphasis, as in earlier sections, is on the dynamics of the trade balance and the terms of trade.

The theoretical economy has the following elements. There are, as before, two countries that specialize in different goods. Preferences of the representative consumer in each country $i$ are characterized by an expected utility function of the form

$$
U_{i}=E_{0} \Sigma_{t=0}^{\infty} \beta^{t} u\left(c_{i t}, 1-n_{i t}\right)
$$

where $c_{i t}$ and $n_{i t}$ are consumption and hours worked in country $i, u(c, 1-n)=$ $\left.\left[c^{\mu}(1-n)\right]^{1-\mu}\right]^{1-\gamma} /(1-\gamma)$, and $\gamma \geq 0$. The primary difference in preferences from the economy of Section 2 is the appearance of leisure in agents' utility functions.

Each country specializes in the production of a single good, labeled "a" for country 1 and "b" for country 2. Each is produced using capital $k$ and labor $n$ with linear homogeneous production functions $F$ of the same form, $F(k, n)=k^{\theta} n^{1-\theta}$. This gives rise to the date-t resource constraints, 


$$
\begin{aligned}
& a_{1 t}+a_{2 t}=y_{1 t}=z_{1 t} F\left(k_{1 t}, n_{1 t}\right), \\
& b_{1 t}+b_{2 t}=y_{2 t}=z_{2 t} F\left(k_{2 t}, n_{2 t}\right),
\end{aligned}
$$

in countries 1 and 2 , respectively. The quantity $y_{i t}$ denotes GDP in country $i$, measured in units of the local good, and $a_{i t}$ and $b_{i t}$ denote uses of the two goods in country i. The vector $z_{t}=\left(z_{1 t}, z_{2 t}\right)$ is a stochastic shock to productivity whose properties will be described shortly. If $\mathrm{k}$ and $\mathrm{n}$ are constant, this reduces to the pure exchange setting of Section 2, with productivity shocks giving rise to proportional output fluctuations.

Consumption, investment, and government spending in each country are composites of the foreign and domestic goods, with

$$
\begin{aligned}
& c_{1 t}+x_{1 t}+g_{1 t}=G\left(a_{1 t}, b_{1 t}\right), \\
& c_{2 t}+x_{2 t}+g_{2 t}=G\left(b_{2 t}, a_{2 t}\right),
\end{aligned}
$$

where, as before, $G(a, b)=\left[\omega a^{1-\alpha}+b^{1-\alpha}\right]^{1 /(1-\alpha)}$. The parameters $\alpha$ and $\omega$ are both positive, and the elasticity of substitution between foreign and domestic goods is $\sigma=1 / \alpha$. As noted earlier, this structure is widely used in static general equilibrium models of trade. Capital stocks evolve according to

$$
\mathrm{k}_{\mathrm{it}+1}=(1-\delta) \mathrm{k}_{\mathrm{it}}+\mathrm{x}_{\mathrm{it}},
$$

where $\delta$ is the depreciation rate. Two differences between this economy and the exchange economy of Sections 2 to 4 are the introduction of capital formation, $x$, and the assumption here that government spending may have some foreign content.

Finally, the underlying shocks to our economy are independent bivariate autoregressions. The technology shocks follow

$$
z_{t+1}=A z_{t}+\varepsilon_{t+1}^{z},
$$

where $\varepsilon^{z}$ is distributed normally and independently over time with variance $v_{z}$. The correlation between the technology shocks, $z_{1}$ and $z_{2}$, is determined by the off-diagonal elements of $A$ and $V_{z}$. Similarly, shocks to government spending are governed by

$$
g_{t+1}=B g_{t}+\varepsilon_{t+1}^{g},
$$

where $g_{t}=\left(g_{1 t}, g_{2 t}\right)$ and $\varepsilon^{g}$ is distributed normally with variance $v_{g}$. 
Technology shocks $\mathrm{z}$ and government spending shocks $\mathrm{g}$ are independent.

With these elements, and the parameter values listed in Table 3, we can approach the behavior of prices and trade. The critical parameters, for our purpose, are the elasticity of substitution, $\sigma$, which we set equal to 1.5 , and the steady state ratio of imports to GDP, which we set equal to 0.15 by choosing $\omega$ appropriately. In this benchmark version of the economy foreign and domestic goods are better substitutes than they would be with Cobb-Douglas preferences and imports are, on average, 85 percent of GDP. The former is consistent with a large number of studies, as documented by Whalley (1985, ch 4). Estimates of the elasticity are generally close to one, of ten slightly larger. The import share is slightly larger than we see in the US, Japan, or an aggregate of European countries (with intra-European trade netted out).

A number of properties of the theoretical economy with alternative parameter settings are reported in Table 4. Consider, first, fluctuations in the terms of trade. The standard deviation of the terms of trade with our benchmark parameter values is 0.48 percent, which is a factor of six less than we see for the US in Table 1. With smaller values of $\sigma$ the theoretical economy generates greater variability of the terms of trade. As illustrated in Figure 2, the standard deviation of $\mathrm{p}$ gets larger as we decrease $\sigma$, and for $\sigma$ less than 0.03 the standard deviation exceeds 2 . Thus it appears that while the theory can produce as much variability in the terms of trade as we see in the data, it requires an elasticity of substitution much smaller than most estimates.

The value of $\sigma$ required to match the variability of the terms of trade in US data is substantially smaller in this model (less than 0.03) than in our calculation in Section 2 for the US and Japan (for which we estimated that $\sigma=0.73$ would be sufficient). Three factors account for most of this difference. The first is that the theoretical economy has, in the benchmark case, about 25 percent less variability in the output ratio than we calculated for Japan and the US. Modifications of the theory that bring the magnitude of business cycles closer to the data will also bring the theory and data closer together with respect to price variability. The second factor is that prices are less variable in the economy with capital formation than in exchange economies. If we eliminate capital (which we can do by 
setting $\theta=0$ in the production function), the economy produces considerably greater price variability, despite less variability in the ratio of outputs. The final factor is the import share. With the import share equal to 0.25 , the variability increases substantially at every value of $\sigma$. For $\sigma=1.5$, the benchmark value, the standard deviation of the relative price rises from 0.48 to 0.58 .

A second property of the model is the contemporaneous correlation between net exports and the terms of trade. In the data this correlation has been positive for the US, negative for Japan and the UK (see Table 1). In the theoretical economy we find, for the benchmark parameter values, that the correlation is -0.41 . As we might expect from Propositions 1 and 2, this correlation is sensitive to the elasticity of substitution. As we see in Figure 3, the correlation increases with $\sigma$, and becomes positive at $\sigma^{*}=2.76$. This feature, too, is strongly influenced by capital formation. In the model without capital $(\theta=0)$ the economy is much like that described in Proposition 2 , with a critical elasticity $\sigma^{*}=0.94$. For $\sigma>\sigma^{*}$ the trade balance and the terms of trade are positively correlated, for $\sigma<\sigma^{*}$ the reverse.

A third property of interest is the impact of government spending on this correlation. We see in Table 4 that with only shocks to government spending, the correlation between net exports and the terms of trade shifts from negative to positive. This mirrors a similar result in Section 5 . With shocks to both productivity, $\mathrm{z}$, and government spending, $\mathrm{g}$, we find that the latter dominate, in the sense that the economy's properties are very similar to those with shocks to productivity alone.

Finally, we look at the complete cross correlation function for net exports and the terms of trade. As pictured in Figure 4, this correlation has the same asymmetric shape we documented for the data in Figure 1 . We initially found this pattern surprising, but its intuitive basis is pictured in Figure 5. Following a favorable productivity shock in the home country, output, $y_{1}$, and the relative price of foreign goods, $p$, both rise. Consumption also rises, but by less than output. Investment rises initially by much more than consumption, as resources are transferred to the home country to exploit its expected productivity advantage. As capital accumulates, this resource transfer diminishes. Thus the trade balance, which is the difference, at market prices, between output and the sum of 
consumption and investment, exhibits an initial period of deficit, followed by surplus. This mechanism is also apparent in the countercyclical movements in the trade balance noted by other studies (see the references in Backus, Kehoe, and Kydland, 1992, Section I).

In short, much of the intuition for this dynamic general equilibrium trade model is available from the exchange economy of Sections 2 to 4 . What the exchange economy misses completely is the dynamics of the relation between the trade balance and the terms of trade: the asymmetric cross correlation function that we documented in the data and labeled the J-curve. The cross correlation function between these two variables is symmetric in the exchange economy, regardless of parameter values. In this section we have seen that the dynamics of capital formation provide a plausible basis for an asymmetric pattern.

\section{Final Thoughts}

We have described how a dynamic general equilibrium approach to aggregate trade theory provides both a new level of understanding of interrelations between trade and price movements and a framework in which these relations can be quantified. With regard to the former, we have seen that the relation between trade and price variables is much different from that suggested by the Marshall-Lerner condition cited in most textbooks. With regard to the latter, we have argued that the dynamic relation between trade and the relative price of foreign goods can be understood as a consequence of the dynamics of capital formation. Thus the dynamics of trade variables are inseparable from the dynamics of the rest of the economy.

Future work will undoubtedly focus, however, not on these contributions, but on dimensions in which the theory, in its current incarnation, provides a relatively poor approximation to actual economies. The most obvious of these is the variability of the terms of trade. In the economy of Section 6, and in Stockman and Tesar (1991) as well, the standard deviation of the terms of trade is substantially smaller than we estimate in the data. This discrepancy between theory and data helps to motivate theories in which monetary policy influences relative prices (Grilli and Roubini 1992, Schlagenhauf and Wrase 1992) and in which international market segmentation, 
possibly in conjunction with imperfect competition, also play a part (Dumas 1992, Giovannini 1988, Lapham 1990). Ongoing research will hopefully tell us how important each of these features is, and how they modify the lessons of the theory outlined above. 


\section{APPENDIX}

The algebra for Section 3 is straightforward but fairly tedious. We start by reducing the economy to two equations in two unknowns. The unknowns are the consumption shares of the first agent, $s_{1}^{a}=a_{1} / y_{1}$ and $s_{1}^{b}=b_{1} / y_{2}$. The foc's and resource constraints then imply

$$
s_{1}^{a} /\left(1-s_{1}^{a}\right)=\omega^{v} s_{1}^{b} /\left(1-s_{1}^{b}\right)
$$

and

$$
\left[\mathrm{s}_{1}^{\mathrm{a}} /\left(1-\mathrm{s}_{1}^{\mathrm{a}}\right)\right]^{\gamma}\left(\lambda_{2} / \omega \lambda_{1}\right)=\left[\left(\omega+\mathrm{m}^{1-\alpha}\right) /\left(1+\omega^{\left.1+v^{1-\alpha}\right)} \mathrm{m}^{(\alpha-\gamma) /(1-\alpha)},\right.\right.
$$

where $m=b_{1} / a_{1}=x s_{1}^{b} / s_{1}^{a}>0$ and $v=2 / \alpha>0$. With these substitutions, the two equations determine $s_{1}^{a}$ and $s_{1}^{b}$ as functions of the endowment ratio $x=y_{2} / y_{1}$. Note that if either $\omega=1$ or $\alpha=\gamma$, the righthand side of (A2) is one and $s_{1}^{2}$ is constant.

Preliminaries. (a) If we differentiate the first equation we get

$$
\mathrm{d}\left[\mathrm{s}_{1}^{\mathrm{a}} /\left(1-\mathrm{s}_{1}^{\mathrm{a}}\right)\right]=\mathrm{ds} \mathrm{a}_{1}^{\mathrm{a}} /\left(1-\mathrm{s}_{1}^{\mathrm{a}}\right)^{2}=\omega^{\mathrm{v}} \mathrm{ds} \mathrm{b}_{1}^{\mathrm{b}} /\left(1-\mathrm{s}_{1}^{\mathrm{b}}\right)^{2}
$$

or

$$
\mathrm{ds}_{1}^{\mathrm{b}} / \mathrm{s}_{1}^{\mathrm{b}}=\left(\mathrm{s}_{1}^{\mathrm{b}} / \mathrm{s}_{1}^{\mathrm{a}}\right) \omega^{\mathrm{v}} \mathrm{ds_{1 }}{ }_{1}^{\mathrm{a}} / \mathrm{s}_{1}^{\mathrm{a}} .
$$

Thus $s_{1}^{a}$ and $s_{1}^{b}$ are positively related and we can substitute out any $d s_{1}^{b}$, we get.

(b) Differentiate the ratio $\left(s_{1}^{b} / s_{1}^{a}\right)$ :

$$
\mathrm{d}\left(\mathrm{s}_{1}^{\mathrm{b}} / \mathrm{s}_{1}^{\mathrm{a}}\right)=\left(\mathrm{s}_{1}^{\mathrm{b}} / \mathrm{s}_{1}^{\mathrm{a}}\right)\left[\left(\mathrm{s}_{1}^{\mathrm{b}} / \mathrm{s}_{1}^{\mathrm{a}}\right) \omega^{\mathrm{v}}-1\right] \mathrm{ds} \mathrm{s}_{1}^{\mathrm{a}} / \mathrm{s}_{1}^{\mathrm{a}} \text {. }
$$

(c) Differentiate m:

$$
\mathrm{dm} / \mathrm{m}=\mathrm{dx} / \mathrm{x}+\left[\left(\mathrm{s}_{1}^{\mathrm{b}} / \mathrm{s}_{1}^{\mathrm{a}}\right) \omega^{\mathrm{v}}-1\right] \mathrm{ds} \mathrm{s}_{1}^{\mathrm{a}} / \mathrm{s}_{1}^{\mathrm{a}} .
$$

(d) Inequalities. From (A1):

$$
\begin{gathered}
s_{1}^{a}>s_{1}^{b} \\
\left(s_{1}^{b} / s_{1}^{a}\right) \omega^{v}-1=\left(s_{1}^{a}-s_{1}^{b}\right) /\left(1-s_{1}^{a}\right)>0 .
\end{gathered}
$$

We now prove the propositions used in the text. 1. We show that $s_{1}^{a}$ is increasing in $x$ if $\gamma>\alpha$, decreasing if $\gamma<\alpha$. We differentiate (A2) and find, after rearrangement: 
(A3)

$$
\gamma\left(w+m^{1-\alpha}\right)\left(1+w^{1+v} m^{1-\alpha}\right) d s_{1}^{a} / s_{1}^{a}=(\alpha-\gamma)\left(1-w^{2+v}\right)\left(1-s_{1}^{a}\right) m^{1-\alpha} d m / m .
$$

If we substitute the expression for $\mathrm{dm}$ [(c) above] we get an equation of the form

$$
A d s_{1}^{a} / s_{1}^{a}=B d x / x
$$

so that $s_{1}^{a}$ is increasing in $x$ if $B / A>0$, decreasing otherwise. The coefficient of $d x / x$ is

$$
B=(\alpha-\gamma)\left(1-\omega^{2+v}\right)\left(1-s_{1}^{a}\right) m^{1-\alpha} .
$$

Since $\omega>1$, B has the same sign as $\gamma-\alpha$. The coefficient of $\mathrm{ds}_{1}^{a} / \mathrm{s}_{1}^{\mathrm{a}}$ is

$$
A=\gamma\left(w+m^{1-\alpha}\right)\left(1+w^{1+v_{m}} m^{1-\alpha}\right)+(\gamma-\alpha)\left(1-\omega^{2+v}\right)\left(s_{1}^{a}-s_{1}^{b}\right) m^{1-\alpha} .
$$

Clearly if $\gamma<\alpha, A$ is positive and $d_{1}^{a} / d x$ is negative. If $\gamma>\alpha$, then

$$
A / \gamma=\left(w+m^{1-\alpha}\right)\left(1+w^{1+v^{1-\alpha}} m^{1-\theta}\left(1-\omega^{2+v}\right) m^{1-\alpha},\right.
$$

where $\theta=\left(s_{1}^{a}-s_{1}^{b}\right)(\gamma-\alpha) / \gamma<1$. Combining terms makes it clear that $A$ is positive in this case, too. Thus the sign of $\mathrm{ds}_{1}^{\mathrm{a}} / \mathrm{dx}$ is the same as the sign of $\gamma-\alpha$.

2. An immediate corollary is that $c_{2} / c_{1}$ is increasing in $x$ : the first order conditions imply

$$
\left[s_{1}^{a} /\left(1-s_{1}^{a}\right)\right]^{\alpha}=\left(\omega \lambda_{2} / \lambda_{1}\right)\left(c_{2} / c_{1}\right)^{\gamma-\alpha} .
$$

The behavior of $s_{1}^{a}$ with respect to $x$ implies that the consumption ratio, $c_{2} / c_{1}$, is increasing in $x$, as claimed in the text.

3. We now show that $b_{1} / a_{1}=m$ is increasing in $x$. From (A3) we have

$$
\begin{gathered}
(\alpha-\gamma)\left(1-w^{2+v}\right)\left(1-s_{1}^{a}\right) m^{1-\alpha} d m / m=\gamma\left(w+m^{1-\alpha}\right)\left(1+w^{1+v} m^{1-\alpha}\right) d s_{1}^{a} / s_{1}^{a} \\
=\gamma\left(w+m^{1-\alpha}\right)\left(1+w^{1+v^{1-\alpha}}\right)(B / A) d x / x .
\end{gathered}
$$

From the definition of $B$,

$$
\text { A dm/m }=\gamma\left(w+m^{1-\alpha}\right)\left(1+w^{1+v} m^{1-\alpha}\right) d x / x \text {. }
$$

Since $A>0, m$ is increasing in $x$.

4. We turn to the dependence of the trade balance on $\mathrm{x}$. As in the text, 


$$
\mathrm{nx}_{1} / \mathrm{y}_{1}=1-\mathrm{s}_{1}^{a}\left[1+\omega^{-1} \mathrm{~m}^{1-\alpha}\right]
$$

Differentiating, we find

$$
\mathrm{d}\left(\mathrm{nx}_{1} / \mathrm{y}_{1}\right)=-\mathrm{ds}_{1}^{\mathrm{a}}\left[1+\omega^{-1} \mathrm{~m}^{1-\alpha}\right]-(1-\alpha) \mathrm{s}_{1}^{\mathrm{a}} \omega^{-1} \mathrm{~m}^{1-\alpha} \mathrm{dm} / \mathrm{m}
$$

which is positive if

$$
\left[1+\omega^{-1} \mathrm{~m}^{1-\alpha}\right] \mathrm{ds}_{1}^{\mathrm{a}} / \mathrm{s}_{1}^{\mathrm{a}}+(1-\alpha) \omega^{-1} \mathrm{~m}^{1-\alpha} \mathrm{dm} / \mathrm{m}<0 .
$$

From (A5) and (A5) we can show that this inequality holds for large enough $\alpha$. 


\section{REFERENCES}

Alterman, William. "Price trends in U.S. trade: New data, new insights," unpublished manuscript, presented at the NBER Conference on Income and Wealth, November 1989.

Armington, Paul. "A theory of demand for products distinguished by place of production," IMF Staff Papers, 27 (1969), 488-526.

Backus, David. "Interpreting comovements in the trade balance and the terms of trade," Journal of International Economics, forthcoming 1992.

Backus, David, Patrick Kehoe, and Finn Kydland. "International real business cycles," Journal of Political Economy, 101 (August 1992), forthcoming.

Backus, David, Patrick Kehoe, and Finn Kydland. "Dynamics of the trade balance and the terms of trade: The J-curve revisited," unpublished manuscript, December 1991.

Baxter, Marianne. "Fiscal policy, specialization, and trade in the two-sector model: The return of Ricardo," Journal of Political Economy, forthcoming 1992.

Cole, Harold, and Obstfeld, Maurice. "Commodity trade and international risk-sharing," Journal of Monetary Economics, 28 (August 1991), 3-24.

Dornbusch, Rudiger. Open Economy Macroeconomics. New York: Basic Books, 1980.

Dumas, Bernard. "Dynamic equilibrium and the real exchange rate in a spatially separated world," Review of Financial Studies, 5 (1992), ...

Ethier, Wilfred J. Modern International Economics, Second Edition, New York: Norton, 1988.

Froot, Kenneth, and Kenneth Rogoff. "Government spending and the real exchange rate in the Bretton Woods era," unpublished manuscript, 1991.

Giovannini, Alberto. "Exchange rates and traded goods prices," Journal of International Economics, 24 (1988), 45-68.

Graboyes, Robert. "International trade and payments data," Federal Reserve Bank of Richmond Quarterly Review, 77 (September/October 1991), 20-31.

Grilli, Vittorio, and Nouriel Roubini. "Liquidity and exchange rates," Journal of International Economics, forthcoming 1992.

Harberger, Arnold. "Currency depreciation, income, and the balance of trade," Journal of Political Economy, 58 (1950), 47-60.

Hodrick, Robert. "U.S. international capital flows: Perspectives from rational maximizing models," Carnegie-Rochester Conference Series on Public Policy, 30 (Spring 1988), 231-288.

Kemp, Murray. "Marshall-Lerner condition." In The New Palgrave: A Dictionary of Economics, London: Macmillan, 1987. 
Krugman, Paul., and Maurice Obstfeld. International Economics: Theory and Policy, Second Edition, New York: HarperCollins, 1991.

Lapham, Beverly. "A dynamic, general equilibrium analysis of deviations from the laws of one price," unpublished manuscript, Queen's University, September 1990.

Laursen, Svend, and Lloyd Metzler. "Flexible exchange rates and the theory of employment," Review of Economics and Statistics, 32 (1950), 281-299.

Macklem, R. Tiff. "Terms-of-trade disturbances and fiscal policy in a small open economy," Bank of Canada Working Paper 90-7, December 1990.

Mendoza, Enrique. "Some international evidence on the correlation between the trade balance and the terms of trade," unpublished manuscript, International Monetary Fund, December 1990.

Mussa, Michael. "Nominal exchange rate regimes and the behavior of real exchange rates," in K.Brunner and A. Meltzer, eds., Real Business Cycles, Real Exchange Rates, and Actual Policies, Carnegie-Rochester Conference Series, 1986.

Obstfeld, Maurice. "Aggregate spending and the terms of trade: Is there a Laursen-Metzler effect?" Quarterly Journal of Economics, 97 (May 1982), 251-270.

Obstfeld, Maurice. "Fiscal deficits and relative prices in a growing economy," Journal of Monetary Economics, 23 (May 1989), 461-484.

Sachs, Jeffrey. "The current account and macroeconomic adjustment in the 1970s," Brookings Papers on Economic Activity, 1: 1981, 201-268.

Schlagenhauf, Don, and Jeffrey Wrase. "A monetary, open-economy model with capital mobility," unpublished manuscript, Arizona State University, 1992.

Stockman, Alan, and Lars E.O. Svensson. "Capital flows, investment, and exchange rates," Journal of Monetary Economics, 19 (1987), 171-201.

Stockman, Alan, and Linda Tesar. "Tastes and technology in a two-country model of the business cycle: Explaining international comovements," unpublished manuscript, November 1990.

Svensson, Lars, and Assaf Razin. "The terms of trade and the current account: The Harberger-Laursen-Metzler effect," Journal of Political Economy, 91 (February 1983), 97-125.

Whalley, John. Trade Liberalization Among Major Trading Areas, Cambridge, MA: MIT Press, 1985.

Yi, Kei-Mu. "Can government purchases explain recent U.S. net export deficits?" unpublished manuscript, presented at the NBER Universities Conference, May 1991. 
Table 1

Properties of the Trade Balance and the Terms of Trade

\begin{tabular}{|c|c|c|c|c|c|c|c|}
\hline \multirow[b]{2}{*}{ Country } & \multirow[b]{2}{*}{ Period } & \multicolumn{2}{|c|}{$\begin{array}{l}\text { Standard } \\
\text { Dev. (\%) }\end{array}$} & \multicolumn{2}{|c|}{ Autocorrelation } & \multicolumn{2}{|c|}{$\begin{array}{c}\text { Cross } \\
\text { Correlation }\end{array}$} \\
\hline & & $\mathrm{p}$ & $\mathrm{nx}$ & $\mathrm{p}$ & $\mathrm{nx}$ & $(p, n x)$ & $(p, y)$ \\
\hline Japan & $\begin{array}{l}1955-89 \\
1955-70 \\
1971-89\end{array}$ & $\begin{array}{l}5.97 \\
2.17 \\
7.76\end{array}$ & $\begin{array}{l}.97 \\
.98 \\
.94\end{array}$ & $\begin{array}{l}.87 \\
.73 \\
.87\end{array}$ & $\begin{array}{l}.77 \\
.66 \\
.83\end{array}$ & $\begin{array}{l}-.46 \\
-.55 \\
-.51\end{array}$ & $\begin{array}{r}-.09 \\
.41 \\
-.27\end{array}$ \\
\hline United Kingdom & $\begin{array}{l}1955-89 \\
1955-70 \\
1971-89\end{array}$ & $\begin{array}{l}2.71 \\
1.51 \\
3.38\end{array}$ & $\begin{array}{r}1.08 \\
.78 \\
1.21\end{array}$ & $\begin{array}{l}.76 \\
.38 \\
.79\end{array}$ & $\begin{array}{l}.66 \\
.54 \\
.65\end{array}$ & $\begin{array}{l}-.54 \\
-.15 \\
-.60\end{array}$ & $\begin{array}{l}.20 \\
.56 \\
.10\end{array}$ \\
\hline United States & $\begin{array}{l}1955-89 \\
1955-70 \\
1971-89\end{array}$ & $\begin{array}{l}2.99 \\
1.31 \\
3.84\end{array}$ & $\begin{array}{l}.45 \\
.30 \\
.55\end{array}$ & $\begin{array}{l}.82 \\
.65 \\
.84\end{array}$ & $\begin{array}{l}.80 \\
.79 \\
.80\end{array}$ & $\begin{array}{l}.30 \\
.28 \\
.30\end{array}$ & $\begin{array}{r}-.09 \\
.47 \\
-.23\end{array}$ \\
\hline
\end{tabular}

NOTES: Variables are: $p$, the terms of trade, logarithm; nx, the ratio of net exports to output; $y$, real output, logarithm. Data are quarterly from the OECD's Quarterly National Accounts. Statistics refer to Hodrick-Prescott filtered variables. 
Table 2

The Trade Balance, the Terms of Trade, and Government Purchases

\begin{tabular}{lcccccccc}
\hline \hline & \multicolumn{3}{c}{$\begin{array}{c}\text { Standard } \\
\text { Deviation }(\%)\end{array}$} & & \multicolumn{4}{c}{ Cross Correlations } \\
\cline { 2 - 6 } \cline { 6 - 9 } Country & $\mathrm{y}$ & $\mathrm{g}$ & & $(\mathrm{p}, \mathrm{nx})$ & $(\mathrm{g}, \mathrm{nx})$ & $(\mathrm{g}, \mathrm{p})$ & $(\mathrm{g}, \mathrm{y})$ \\
\hline Australia & 1.47 & 1.90 & & -.11 & -.15 & .15 & .17 \\
Austria & 1.27 & .45 & & -.25 & .11 & .28 & -.23 \\
Canada & 1.49 & 1.16 & & -.06 & -.15 & -.02 & -.22 \\
France & .91 & .66 & & -.50 & .11 & -.45 & .24 \\
Germany & 1.47 & 1.22 & & -.09 & -.11 & -.16 & .23 \\
Italy & 1.70 & .69 & & -.66 & .11 & -.42 & -.01 \\
Japan & 1.48 & 1.54 & & -.51 & .19 & -.35 & .02 \\
Switzerland & 1.94 & 1.01 & & -.61 & -.15 & -.29 & .28 \\
United Kingdom & 1.60 & 1.07 & & -.60 & -.06 & -.01 & .06 \\
United States & 1.93 & 1.47 & & .31 & -.28 & .13 & .12 \\
\hline \hline
\end{tabular}

NOTES: The sample period is 1971:1 to 1989:4. Variables are: p, the terms of trade, logarithm; nx, the ratio of net exports to output; y, real output, logarithm; $g$, real government purchases of goods and services, logarithm. Data are quarterly from the OECD's Quarterly National Accounts. Statistics refer to Hodrick-Prescott filtered variables. 


\section{Table 3}

Benchmark Parameter Values

\begin{tabular}{ll}
\hline \hline Preferences & $\beta=.99, \quad \mu=.34, \quad \gamma=2.0$ \\
Technology & $\theta=.36, \quad \delta=.025, \quad \sigma=1 /(1+\rho)=1.5$, \\
& import share $=15$ \\
Forcing Processes & $\mathrm{A}=\left[\begin{array}{ll}\mathrm{a}_{11} & \mathrm{a}_{12} \\
\mathrm{a}_{12} & \mathrm{a}_{11}\end{array}\right]=\left[\begin{array}{ll}.906 & .088 \\
.088 & .906\end{array}\right]$ \\
& $\operatorname{var} \epsilon_{1}^{\mathrm{z}}=\mathrm{var}_{2}^{\mathrm{z}}=.00852^{2}, \quad \operatorname{corr}\left(\epsilon_{1}^{\mathrm{z}}, \epsilon_{2}^{\mathrm{z}}\right)=$ \\
.258 & \\
$\mathrm{~g}_{\mathrm{t}}=0$
\end{tabular}


Table 4

Properties of Theoretical Economies with Capital Formation

\begin{tabular}{|c|c|c|c|c|c|c|c|c|c|}
\hline \multirow[b]{2}{*}{ Economy } & \multicolumn{3}{|c|}{$\begin{array}{c}\text { Standard } \\
\text { Deviation (\%) }\end{array}$} & \multicolumn{3}{|c|}{ Autocorrelation } & \multicolumn{3}{|c|}{ Correlation } \\
\hline & $\mathrm{nx}$ & $\mathrm{y}$ & $\mathrm{p}$ & $\mathrm{nx}$ & $\mathrm{y}$ & $\mathrm{p}$ & $(\mathrm{nx}, \mathrm{y})$ & $(n x, p)$ & $(y, p)$ \\
\hline Benchmark & $\begin{array}{l}.30 \\
(.02)\end{array}$ & $\begin{array}{l}1.38 \\
(.18)\end{array}$ & $\begin{array}{l}.48 \\
(.06)\end{array}$ & $\begin{array}{l}.61 \\
(.07)\end{array}$ & $\begin{array}{c}.63 \\
(.10)\end{array}$ & $\begin{array}{l}.83 \\
(.05)\end{array}$ & $\begin{array}{l}-.64 \\
(.07)\end{array}$ & $\begin{array}{c}-.41 \\
(.08)\end{array}$ & $\begin{array}{r}.49 \\
(.14)\end{array}$ \\
\hline $\begin{array}{l}\text { Large } \\
\text { Elasticity }\end{array}$ & $\begin{array}{l}.33 \\
(.03)\end{array}$ & $\begin{array}{l}1.41 \\
(.18)\end{array}$ & $\begin{array}{l}.35 \\
(.05)\end{array}$ & $\begin{array}{l}.63 \\
(.07)\end{array}$ & $\begin{array}{c}.64 \\
(.18)\end{array}$ & $\begin{array}{l}.88 \\
(.03)\end{array}$ & $\begin{array}{l}-.57 \\
(.08)\end{array}$ & $\begin{array}{l}-.05 \\
(.09)\end{array}$ & $\begin{array}{l}.43 \\
(.14)\end{array}$ \\
\hline $\begin{array}{l}\text { Small } \\
\text { Elasticity }\end{array}$ & $\begin{array}{l}.37 \\
(.03)\end{array}$ & $\begin{array}{l}1.33 \\
(.18)\end{array}$ & $\begin{array}{l}.76 \\
(.07)\end{array}$ & $\begin{array}{l}.61 \\
(.07)\end{array}$ & $\begin{array}{c}.63 \\
(.10)\end{array}$ & $\begin{array}{l}.77 \\
(.05)\end{array}$ & $\begin{array}{l}-.66 \\
(.07)\end{array}$ & $\begin{array}{l}-.80 \\
(.09)\end{array}$ & $\begin{array}{l}.51 \\
(.16)\end{array}$ \\
\hline Big Share & $\begin{array}{l}.63 \\
(.04)\end{array}$ & $\begin{array}{l}1.37 \\
(.18)\end{array}$ & $\begin{array}{l}.58 \\
(.08)\end{array}$ & $\begin{array}{l}.59 \\
(.07)\end{array}$ & $\begin{array}{c}.64 \\
(.10)\end{array}$ & $\begin{array}{l}.83 \\
(.04)\end{array}$ & $\begin{array}{l}-.61 \\
(.07)\end{array}$ & $\begin{array}{l}-.41 \\
(.07)\end{array}$ & $\begin{array}{l}.52 \\
(.13)\end{array}$ \\
\hline Small Share & $\begin{array}{l}.08 \\
(.01)\end{array}$ & $\begin{array}{l}1.38 \\
(.18)\end{array}$ & $\begin{array}{c}.43 \\
(.06)\end{array}$ & $\begin{array}{r}.62 \\
(.07\end{array}$ & $\begin{array}{l}.63 \\
(.10)\end{array}$ & $\begin{array}{l}.81 \\
(.05)\end{array}$ & $\begin{array}{l}-.65 \\
(.07)\end{array}$ & $\begin{array}{c}-.41 \\
(.08)\end{array}$ & $\begin{array}{l}.48 \\
(.14)\end{array}$ \\
\hline Two Shocks & $\begin{array}{l}.33 \\
(.03)\end{array}$ & $\begin{array}{l}1.33 \\
(.15)\end{array}$ & $\begin{array}{l}.57 \\
(.07)\end{array}$ & $\begin{array}{l}.62 \\
(.08)\end{array}$ & $\begin{array}{l}.65 \\
(.08)\end{array}$ & $\begin{array}{l}.78 \\
(.06)\end{array}$ & $\begin{array}{l}-.57 \\
(.15)\end{array}$ & $\begin{array}{l}-.05 \\
(.17)\end{array}$ & $\begin{array}{l}.39 \\
(.17)\end{array}$ \\
\hline $\begin{array}{l}\text { Government } \\
\text { Shocks }\end{array}$ & $\begin{array}{l}.16 \\
(.03)\end{array}$ & $\begin{array}{l}.17 \\
(.02)\end{array}$ & $\begin{array}{l}.30 \\
(.05)\end{array}$ & $\begin{array}{l}.67 \\
(.11)\end{array}$ & $\begin{array}{l}.67 \\
(.08)\end{array}$ & $\begin{array}{l}.67 \\
(.11)\end{array}$ & $\begin{array}{l}-.55 \\
(.13)\end{array}$ & $\begin{array}{l}1.00 \\
(.00)\end{array}$ & $\begin{array}{l}-.55 \\
(.13)\end{array}$ \\
\hline
\end{tabular}

NOTES: Statistics are based on Hodrick-Prescott (1980) filtered data. Entries are averages over 50 simulations of 100 quarters each; numbers in parentheses are standard deviations. Parameters as in Table 3, except: large elasticity, $\sigma=2.5$; small elasticity, $\sigma=0.5$; big share, import share $=0.25$; small share, import share $=0.05$; two shocks, mean of $\mathrm{g}=\operatorname{diag}(.2, .2), \mathrm{B}=\operatorname{diag}(.95, .95)$, and $\mathrm{V}_{\mathrm{g}}=$ $\operatorname{diag}\left(.004^{2}, .004^{2}\right)$; government shocks, as in two shocks plus $z_{t}=1$, all t. 
Figure 1. J-Curves in the Data
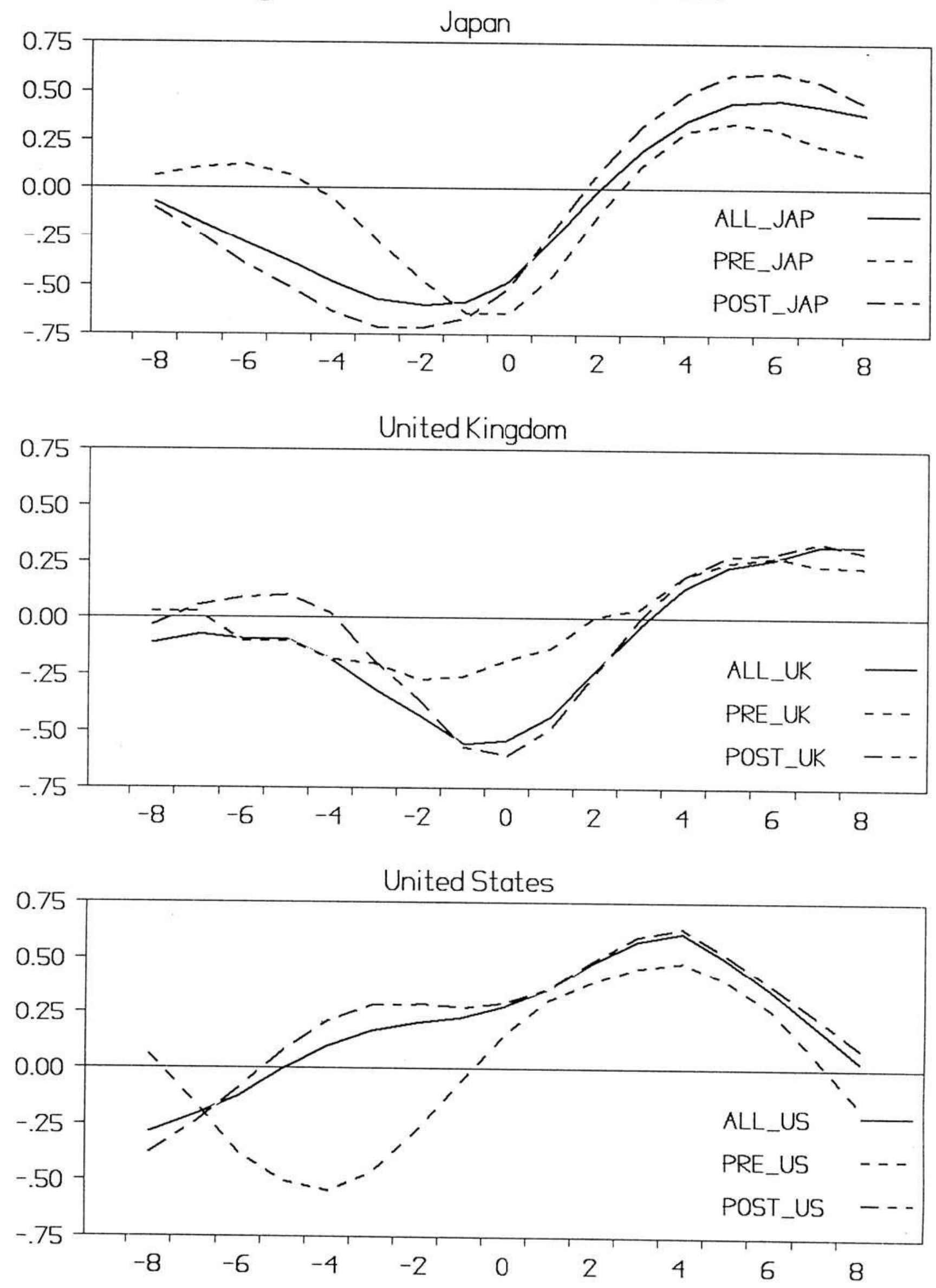
Figure 2

Variability of the Terms of Trade

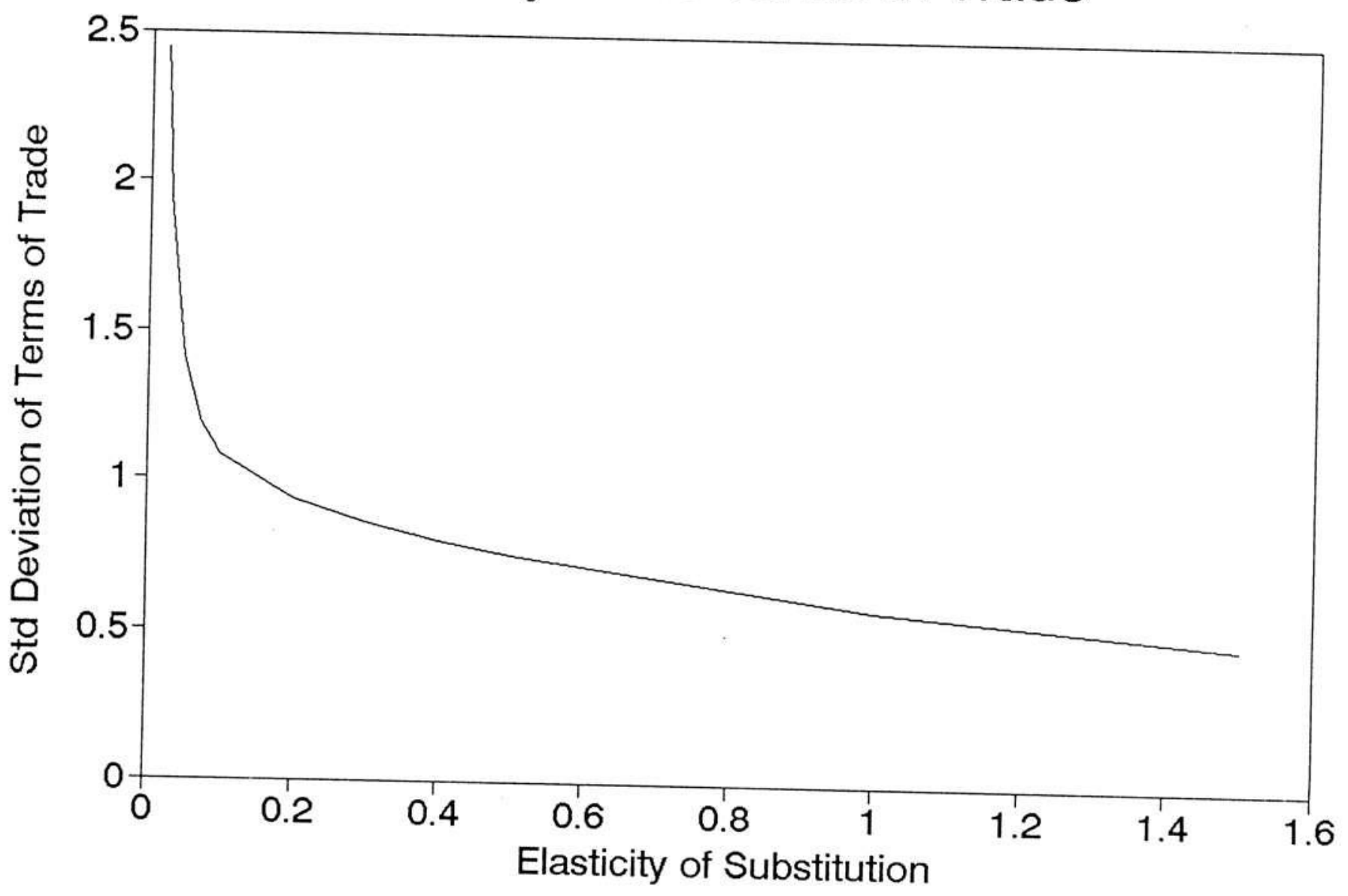


Figure 3

The Trade Balance and Terms of Trade

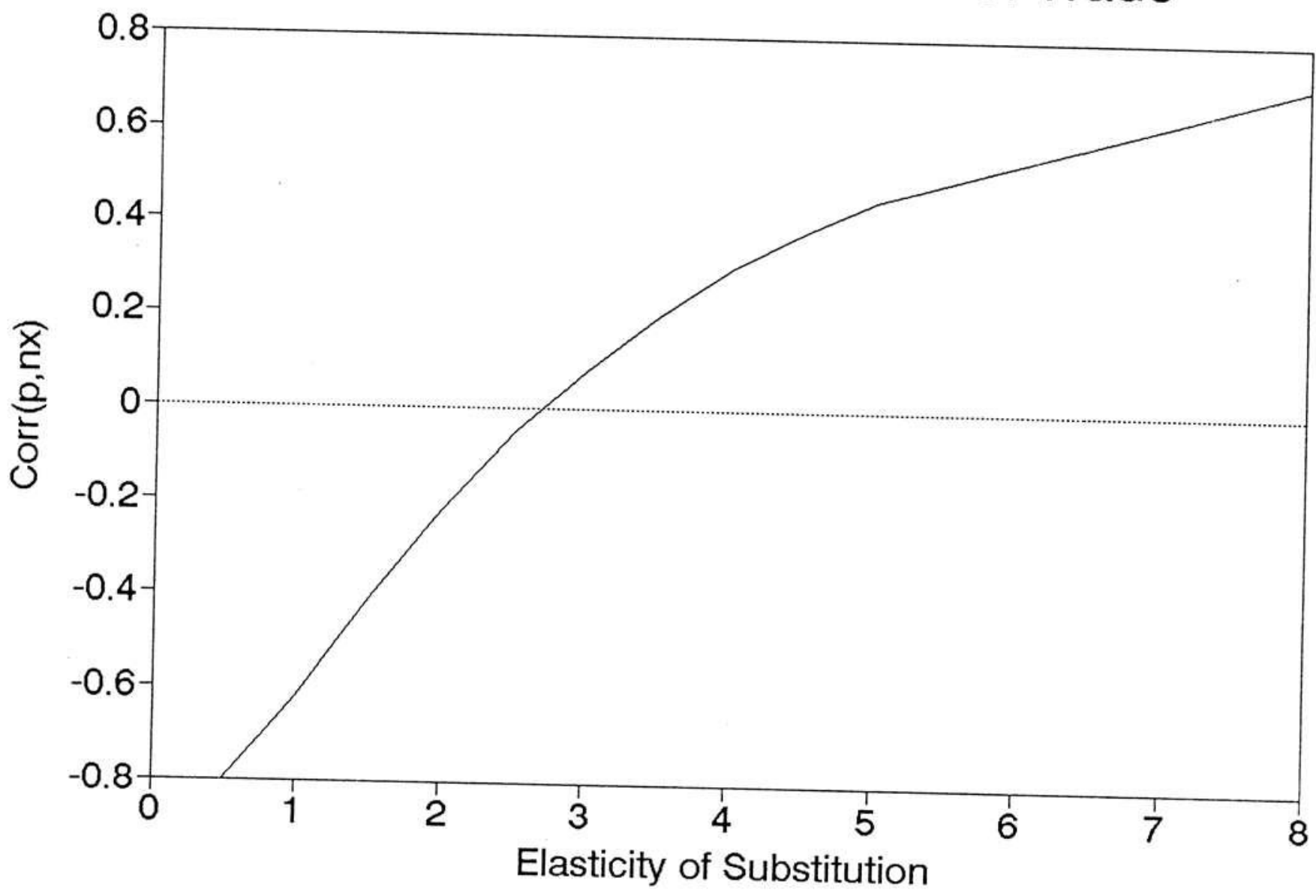


Figure 4

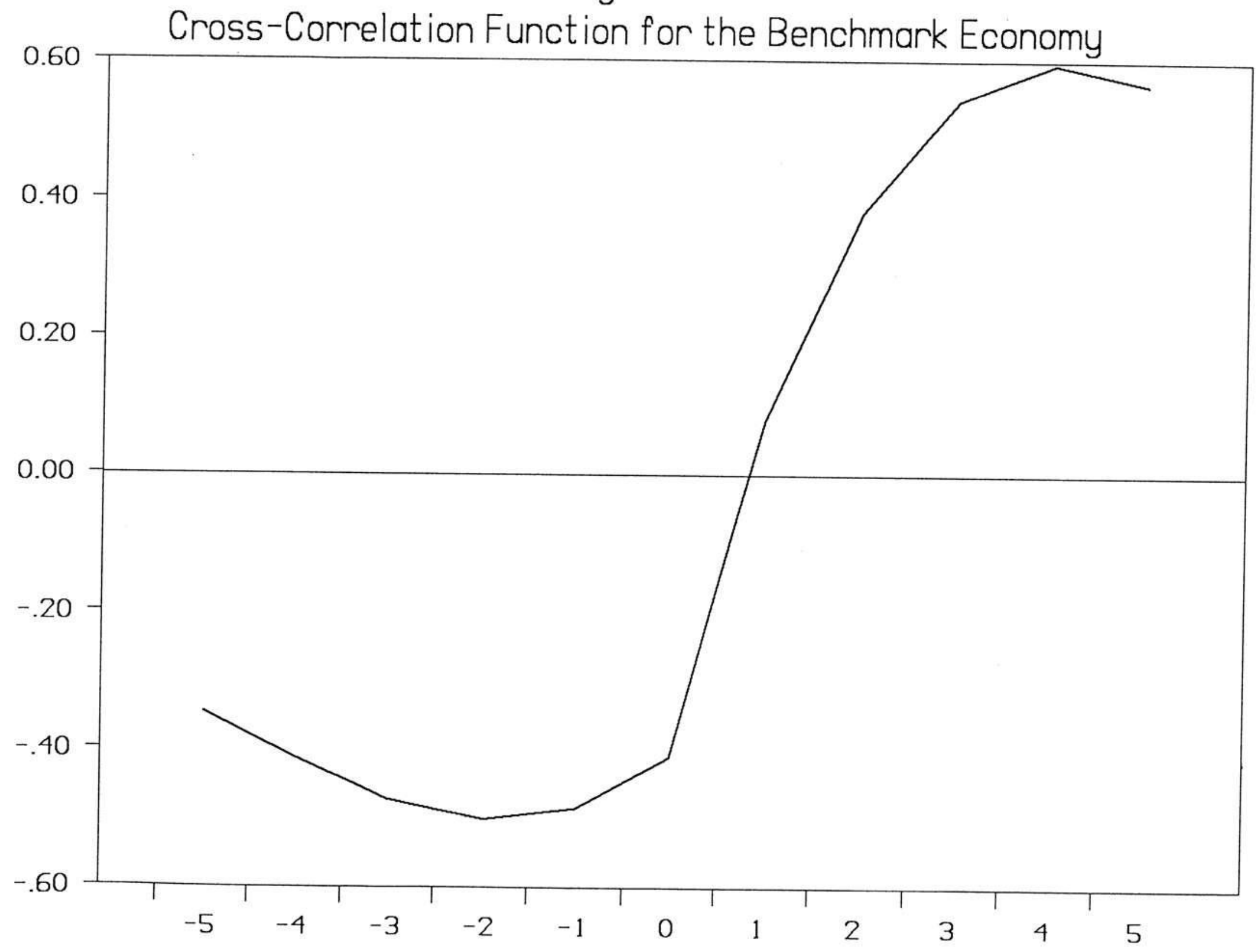


Figure 5
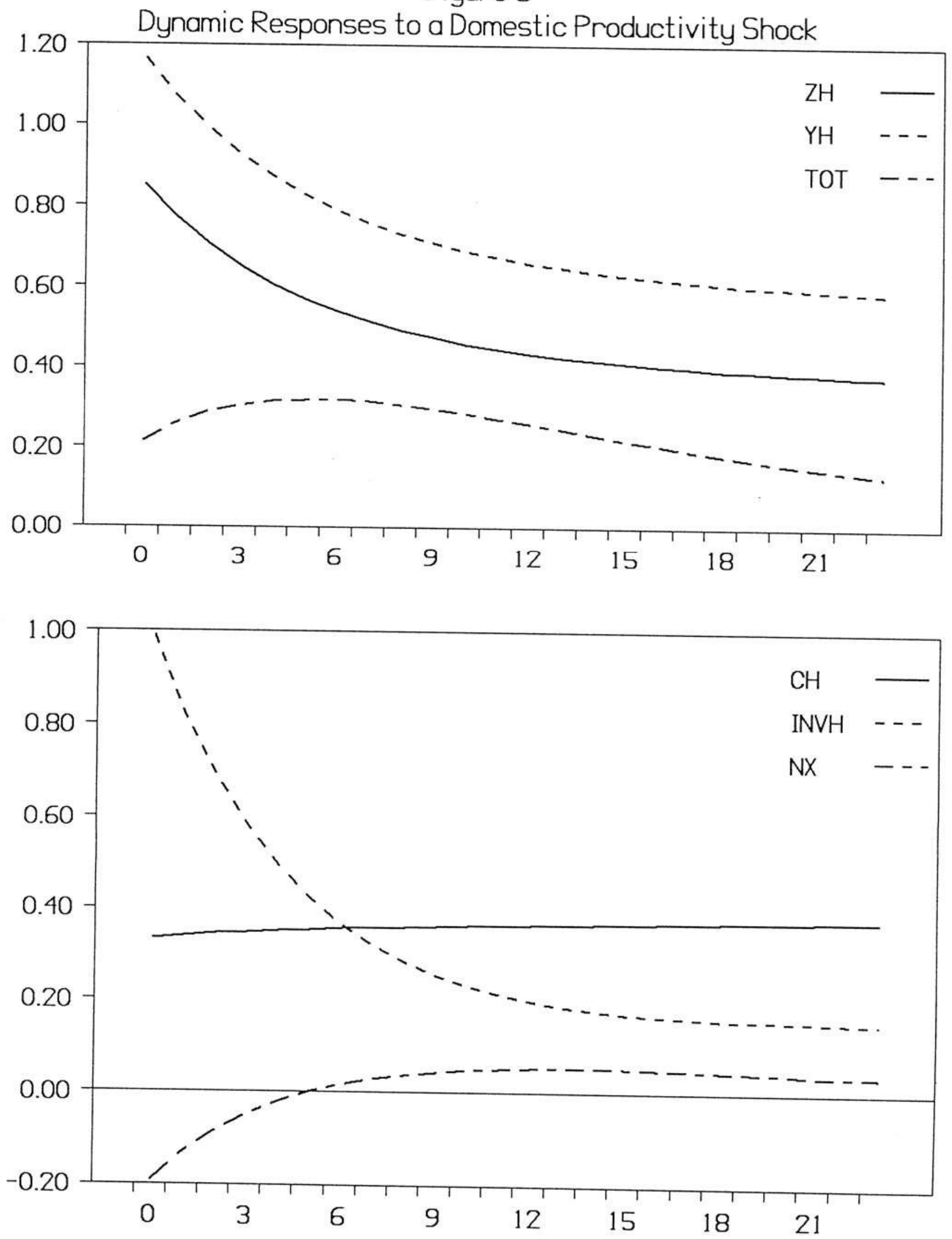